\title{
Evaluation of UTLS carbon monoxide simulations in GMI and GEOS-Chem chemical transport models using Aura MLS observations
}

\author{
Lei Huang ${ }^{1}$, Jonathan H. Jiang ${ }^{1}$, Lee T. Murray ${ }^{2,3}$, Megan R. Damon ${ }^{4}$, Hui Su ${ }^{1}$, and Nathaniel J. Livesey ${ }^{1}$ \\ ${ }^{1}$ Jet Propulsion Laboratory, California Institute of Technology, Pasadena, CA, USA \\ ${ }^{2}$ NASA Goddard Institute for Space Studies, New York, NY, USA \\ ${ }^{3}$ Lamont-Doherty Earth Observatory, Columbia University, Palisades, NY, USA \\ ${ }^{4}$ NASA Goddard Space Flight Center, Greenbelt, MD, USA \\ Correspondence to: Lei Huang (Lei.Huang@jpl.nasa.gov)
}

Received: 3 February 2016 - Published in Atmos. Chem. Phys. Discuss.: 15 February 2016

Revised: 19 April 2016 - Accepted: 28 April 2016 - Published: 9 May 2016

\begin{abstract}
This study evaluates the distribution and variation of carbon monoxide $(\mathrm{CO})$ in the upper troposphere and lower stratosphere (UTLS) during 2004-2012 as simulated by two chemical transport models, using the latest version of Aura Microwave Limb Sounder (MLS) observations. The simulated spatial distributions, temporal variations and vertical transport of CO in the UTLS region are compared with those observed by MLS. We also investigate the impact of surface emissions and deep convection on $\mathrm{CO}$ concentrations in the UTLS over different regions, using both model simulations and MLS observations. Global Modeling Initiative (GMI) and GEOS-Chem simulations of UTLS CO both show similar spatial distributions to observations. The global mean $\mathrm{CO}$ values simulated by both models agree with MLS observations at 215 and $147 \mathrm{hPa}$, but are significantly underestimated by more than $40 \%$ at $100 \mathrm{hPa}$. In addition, the models underestimate the peak $\mathrm{CO}$ values by up to $70 \%$ at $100 \mathrm{hPa}, 60 \%$ at $147 \mathrm{hPa}$ and $40 \%$ at $215 \mathrm{hPa}$, with GEOS-Chem generally simulating more $\mathrm{CO}$ at $100 \mathrm{hPa}$ and less $\mathrm{CO}$ at $215 \mathrm{hPa}$ than GMI. The seasonal distributions of CO simulated by both models are in better agreement with MLS in the Southern Hemisphere (SH) than in the Northern Hemisphere (NH), with disagreements between model and observations over enhanced $\mathrm{CO}$ regions such as southern Africa. The simulated vertical transport of CO shows better agreement with MLS in the tropics and the SH subtropics than the NH subtropics. We also examine regional variations in the relationships among surface $\mathrm{CO}$ emission, convection and UTLS CO concentrations. The two models exhibit emission-convection-
\end{abstract}

CO relationships similar to those observed by MLS over the tropics and some regions with enhanced UTLS CO.

\section{Introduction}

Carbon monoxide (CO) plays important roles in atmospheric chemistry and radiation balance. In particular, it serves as the primary sink of the hydroxyl radical $(\mathrm{OH})$ (Logan et al., $1981)$ and is an important tropospheric ozone $\left(\mathrm{O}_{3}\right)$ precursor (Daniel and Solomon, 1998). CO in the troposphere is mostly emitted from the surface as a byproduct of incomplete combustion of carbon-based fuels, and it has primary sources from fossil fuel and biomass burning as well as secondary sources from oxidation of methane and other hydrocarbons (Jacob, 1999; Shindell et al., 2006). CO can be rapidly uplifted into middle and upper troposphere by convection, where it can be transported around the globe (Jiang et al., 2007). With a typical lifetime of 1-2 months in the troposphere, $\mathrm{CO}$ has been often used as a tracer for studying the transport of polluted air masses that originate in regions of biomass burning or fossil fuel combustion (e.g., Allen et al., 1996; Edwards et al., 2006; Huang et al., 2012).

Previous studies using both satellite observations and model simulations have shown that $\mathrm{CO}$ has strong seasonal and interannual variations in the upper troposphere and lower stratosphere (UTLS) (e.g., Schoeberl et al., 2006; Liu et al., 2007, 2010, 2013; Huang et al., 2012, 2014). Temporal varia- 
tions of CO in the UTLS are affected by many factors, including surface emission and convection, each having different seasonal variations, as well as photochemistry and transport, which can affect $\mathrm{CO}$ concentrations either locally or across a long distance. Schoeberl et al. (2006) studied vertical transport of CO across UTLS by analyzing the "tape recorder" the vertical and temporal variations of $\mathrm{CO}$ observed by the Aura Microwave Limb Sounder (MLS) during August 2004 to December 2005. Their study indicates that the CO tape recorder arises from combined seasonal variations in both surface emissions and convective transport of $\mathrm{CO}$ into the upper troposphere (UT). These can be simulated by the Global Modeling Initiative (GMI) chemical transport model (CTM) forced by climatological emissions. Many other studies also have shown that convolved seasonality in surface emissions and deep convective activity jointly produce enhanced $\mathrm{CO}$ fluxes from the surface to the UT resulting in seasonal peaks of CO (e.g., Liu et al., 2007, 2010; Huang et al., 2012). Strong interannual variation of CO in the UT has been found to be mainly associated with intense drought-induced fires in Indonesia and South America during El Niño periods (Liu et al., 2013; Livesey et al., 2013; Huang et al., 2014).

Although both surface emissions and convective transport could influence the seasonal peaks of CO in the UTLS, the relative importance of each factor varies between regions. Liu et al. (2007) suggested that high CO concentrations in the tropical UT during boreal spring are mainly caused by a number of intense convective events over Africa and the Amazon that transport large amounts of fire-generated $\mathrm{CO}$ to the tropical tropopause layer. Ricaud et al. (2007) found that the peak in $\mathrm{CO}$ at the tropopause over Africa during boreal spring largely results from convective and large-scale horizontal transport pathways, regardless of source region. Further study by Huang et al. (2012) confirmed that the locations and seasonality of the UT CO maxima in the tropics were strongly correlated with the frequency of local convection over South America and central Africa during 2007. However, Schoeberl et al. (2006), using model simulations, argued that the UT CO maximum mainly results from strong biomass burning in Indochina. Gonzi and Palmer (2010) further found that the fractions of surface $\mathrm{CO}$ emissions transported to the UT are lower over Africa and South America than over Indonesia during June to October 2006. Although the relationships among emissions, convection, dynamical transport and UTLS CO abundance have been investigated by some observational studies (e.g., Jiang et al., 2007; Huang et al., 2012; Livesey et al., 2013), it is still not clear whether models can reproduce these relationships.

The ability of global CTMs to capture the processes driving $\mathrm{CO}$ temporal and spatial variations needs to be evaluated with observations. However, most of the previous model evaluation studies have been limited to comparison with in situ surface observations (e.g., Duncan et al., 2007), in situ aircraft field campaigns with limited spatial and temporal coverage (e.g., Hudman et al., 2007; Fisher et al., 2015) and ground- or satellite-based remotely sensed total column or coarse-resolution vertical profile data (e.g., Edwards et al., 2006; Gloudemans et al., 2006; De Laat et al., 2007; Naik et al., 2013; Zeng et al., 2015). There are also some model inversion studies on CO sources (e.g., Heald et al., 2004; Kopacz et al., 2009), including a few studies using vertical CO information from multiple satellite products (e.g., Kopacz et al., 2010). Shindell et al. (2006) evaluated seasonal and spatial distributions of surface CO in 26 global atmospheric chemistry models and found that these models generally underestimate extratropical $\mathrm{CO}$ concentration in the Northern Hemisphere, although they typically perform reasonably well elsewhere. Fisher et al. (2015) showed large variabilities in the ability of different models to reproduce the observed $\mathrm{CO}$ profiles, and more complex chemical mechanisms do not necessarily produce more accurate simulation of CO vertical gradients. Zeng et al. (2015) compared simulated $\mathrm{CO}$ to observations from ground-based total column measurements at selected Southern Hemisphere (SH) sites and found that accurate representation of biogenic emissions is critical to reproducing observed SH background CO. Although total column comparisons provide an advantage over in situ surface comparisons for model validation in the free troposphere, neither surface nor total column data were able to constrain the vertical structure of $\mathrm{CO}$ in the models. Since 2004, the MLS instrument aboard the Aura satellite has been providing vertical profile measurements of various trace gases (e.g., $\mathrm{CO}, \mathrm{H}_{2} \mathrm{O}, \mathrm{O}_{3}$ ) in the UTLS, which have been widely used for trace gas distribution and transport studies (e.g., Park et al., 2009; Liu at al., 2010, 2013; Randel et al., 2010; Huang et al., 2012, 2014; Randel and Jensen, 2013). For example, Park et al. (2009) studied the source and transport of $\mathrm{CO}$ in the Asian monsoon circulation by using chemistry transport model simulation and MLS observation. Randel et al. (2010) identified the transport of polluted air masses from the surface to the stratosphere during Asian monsoon season by using MLS observation of hydrogen cyanide (HCN). Liu et al. (2010) evaluated CO transport in the GEOS-Chem CTM driven by GEOS-4 and GEOS-5 assimilated meteorological fields and discussed the differences with MLS observations. Huang et al. $(2012,2014)$ developed a method to automate the identification of convective transport pathways of CO through a joint use of MLS and A-Train satellite measurements and applied this method to study factors affecting the seasonal and interannual variations of tropical UT CO.

This study aims to evaluate the $\mathrm{CO}$ concentration and its distribution and variation in the UTLS during 20042012 simulated by two state-of-the-art CTMs using the latest version (V4.2) of Aura MLS data. The two models we use are GMI and GEOS-Chem. We will investigate whether the models can reproduce the relationships between surface CO emissions, convection and UTLS CO concentration seen in proxy and direct observations. Section 2 introduces the Aura MLS data and model simulations used. Section 3 com- 
pares model-simulated climatological seasonal distributions, monthly variations and tape recorder signal of $\mathrm{CO}$ in the UTLS with the MLS observations. Section 4 analyzes and discusses the discrepancies in CO in the UTLS over selected regions between the model simulations and MLS observations. Section 5 investigates the convolved impacts of $\mathrm{CO}$ emissions and convection on UTLS CO concentrations in both the satellite observation and model simulations. The main conclusions of this study are summarized and discussed in Sect. 6.

\section{Data}

\subsection{Aura MLS observations}

The MLS instrument aboard the Aura satellite was launched on 15 July 2004. Aura has a sun-synchronous orbit at an altitude of $705 \mathrm{~km}$, with equatorial crossing times at 01:45 and 13:45 local solar time and a 16-day repeat cycle. MLS makes measurements of atmospheric composition, temperature, humidity and cloud ice in the upper troposphere and stratosphere by measuring thermal microwave emissions from broad spectral bands with a limb-viewing geometry (Waters et al., 2006). An advantage of MLS is that its measurements can be obtained in the presence of ice clouds and aerosols that prevent measurements by shorter wavelength infrared, visible and ultraviolet techniques. MLS observes $\mathrm{CO}$ at $240 \mathrm{GHz}$, with a vertical resolution of $\sim 5 \mathrm{~km}$ in the UTLS and horizontal resolutions of $\sim 6$ and $500-600 \mathrm{~km}$ across- and along-track, respectively (Livesey et al., 2008). An earlier version of the MLS CO retrieval (V2.2) was biased high by a factor of 2 at $215 \mathrm{hPa}$, although the morphology was generally realistic (Livesey et al., 2008). In a later version (V3.3), the high positive bias at $215 \mathrm{hPa}$ was removed, but the impact of deep clouds on CO observations was considerably worse (Livesey et al., 2011). The newest version (V4.2) of the MLS data (Livesey et al., 2015) was released in July 2015, and reduces the cloud impacts seen in V3.3, while avoiding the biases associated with V2.2. Comparisons of UTLS CO between the new (V4.2) and previous (V3.3) versions are discussed in Appendix A (Figs. A1 and A2). Only thick clouds that are typically associated with deepconvective cores are observable by MLS (Wu et al., 2008); thus MLS cloud ice water content (IWC) has been used as a proxy of deep convection in previous studies (e.g., Jiang et al., 2011; Liu et al., 2013; Livesey et al., 2013). In this study, we use MLS V4.2 Level 2 CO and IWC data, screening the data using recommended procedures (Livesey et al., 2015). The lowest usable retrieval level for CO and IWC is $215 \mathrm{hPa}$, where the estimated single-measurement precisions are $\sim 19 \mathrm{ppbv}$ for $\mathrm{CO}$ and $\sim 1.2 \mathrm{mg} \mathrm{m}^{-3}$ for IWC. The systematic uncertainty for $\mathrm{CO}$ at $215 \mathrm{hPa}$ is $\pm 30 \mathrm{ppbv}$ and $\pm 30 \%$, and generally $\pm 30 \%$ at other UTLS pressure levels (Livesey et al., 2015).

\subsection{GMI and GEOS-Chem model simulations}

\subsubsection{GMI model}

The GMI is a global 3-D CTM that includes full chemistry for both the troposphere and stratosphere. The GMI model is an assessment tool as part of the NASA Modeling, Analysis and Prediction (MAP) program. It is capable of multiyear simulations for assessments of anthropogenic impacts on atmospheric composition and the role of long-range transport of pollution (Rotman et al., 2001). The GMI model includes a combined stratosphere-troposphere chemical mechanism with 124 species, 320 chemical reactions and 81 photolytic reactions. The chemical mechanism in the troposphere includes a detailed description of tropospheric ozone, $\mathrm{NO}_{x}$ and hydrocarbon photochemistry (Bey et al., 2001a). Photolysis rates in the troposphere and stratosphere are calculated by using the Fast-JX radiative transfer algorithm (Wild et al., 2000; Bian and Prather, 2002), which is an efficient algorithm for calculating photolysis rates in the presence of clouds and aerosols. Radiative and heterogeneous effects of aerosols on photochemistry are included in this model. Biogenic emissions of isoprene and monoterpenes are calculated online (Guenther et al., 2006). Surface methane is read from climatological monthly files, and allowed to advect and react. Convective transport of trace gases is parameterized using a modified CONV_TRAN routine contained in the NCAR CCM3 physics package (Kiehl et al., 1998).

The time period of the GMI hindcast simulation is 19902012, with 1990-1994 considered as the hindcast spin-up period. Therefore, the GMI simulation used in this analysis is for 2004 through 2012. The meteorological fields are from the Global Modeling and Assimilation Office (GMAO) Modern-Era Retrospective Analysis for Research and Applications (MERRA) reanalysis (Rienecker et al., 2011). The MERRA data have 72 vertical levels with a top at $0.01 \mathrm{hPa}$, and the horizontal resolution is $1 / 2^{\circ}$ latitude $\times 2 / 3^{\circ}$ longitude, which has been degraded to $2^{\circ}$ latitude $\times 2.5^{\circ}$ longitude for input to the CTM. The biomass burning emissions used in the simulation are from the Global Fire Emission Database version 3 (GFED3) (van der Werf et al., 2010). The fossil fuel (FF) emissions are based on the Emission Database for Global Atmospheric Research (EDGAR) v3.2 inventory for 2000, overwritten with regional inventories over specific regions (Zhang et al., 2009, inventory for 2006 over Asia, EPA NEI 2005 over the United States, EMEP over Europe, BRAVO over Mexico, CAC over Canada). The year-to-year variability in the FF emissions is calculated wherever the inventories have year-specific information. Otherwise, scaling factors from GEOS-Chem model (van Donkelaar et al., 2008) are used to make the FF emissions year-specific. However, at the time when the GMI emissions were generated, the GEOS-Chem scaling factors ended in 2006, so for 20072012, the US emissions were scaled based on EPA emission totals for each year and the European emissions were 
Table 1. Differences between GMI model and GEOS-Chem model run.

\begin{tabular}{lcc}
\hline & GMI & GEOS-Chem \\
\hline Spin-up period & $1990-1994$ & January 2003-April 2004 \\
Vertical resolution & 72 levels $(\sim 38$ levels & 47 levels $(\sim 38$ levels \\
& in the tropical troposphere $)$ & in the tropical troposphere $)$ \\
Number of species & 124 & 155 \\
Number of chemical reactions & 320 & 292 \\
Number of photolytic reactions & 81 & 64 \\
Chemistry mechanism & Combined stratosphere/troposphere & Fully resolved in the troposphere, a linearized \\
& chemical mechanism & scheme applied in the stratosphere \\
Convective parameterization & NCAR convection scheme & Relaxed Arakawa-Schubert scheme
\end{tabular}

scaled on a country-wide basis using national emissions from EMEP and the Asian emissions were scaled using the REAS inventory projections. Biofuel emissions are from Yevich and Logan (2003) and EPA emission inventory.

\subsubsection{GEOS-Chem model}

GEOS-Chem is a global 3-D CTM developed by the atmospheric chemistry group at Harvard University and has been widely used around the world. It is driven by assimilated meteorological observations from the NASA GMAO Goddard Earth Observing System (GEOS) (Bey et al., 2001b). GEOS-Chem includes a fully coupled treatment of tropospheric $\mathrm{O}_{3}-\mathrm{NO}_{x}-\mathrm{VOC}$ chemistry and various types of aerosols (e.g., Park et al., 2003; Alexander et al., 2005), along with 155 species, 292 chemical reactions and 64 photolytic reactions. Chemistry is fully resolved in the troposphere, with a linearized scheme applied in the stratosphere (Murray et al., 2013). Emissions in GEOS-Chem are from the same several basic inventories as used by GMI, with annual scaling factors applied to account for trends. As for GMI, the Fast-JX radiative transfer algorithm is used in GEOS-Chem. Anthropogenic non-methane volatile organic compounds (NMVOCs) are emitted from the REanalysis of the TROpospheric chemical composition (RETRO) inventory (Schultz et al., 2007), except for propane and ethane, which follow Xiao et al. (2008). Biogenic NMVOC emissions follow the Model of Emissions and GAses from Nature (MEGAN), which vary monthly with observations of leaf area indices from satellite and hourly with temperature, radiation and precipitation (Barkley et al., 2011). Surface methane is read from monthly mean distributions interpolated from NOAA flask observations, and allowed to advect and react. Convective transport in GEOS-Chem is computed from the convective mass fluxes in the meteorological archive, as described by $\mathrm{Wu}$ et al. (2007). In this study, we use the simulations of GEOS-Chem version 902 (www.geos-chem.org) driven by MERRA reanalysis, the same meteorological fields as the GMI simulations. Vertical resolution is degraded from that of the MERRA inputs above $78.5 \mathrm{hPa}$ but maintained at the MERRA resolution below,
Table 2. Annual mean and interannual standard deviation of $\mathrm{CO}$ budgets (biofuel and fossil fuel emissions, biomass burning emissions, tropospheric chemical production, tropospheric methane oxidation, loss with tropospheric $\mathrm{OH}$ and net transport from troposphere to stratosphere) for GMI and GEOS-Chem during 20042012 (units in Tmol year ${ }^{-1}$ ).

\begin{tabular}{lcc}
\hline Model & GMI & GEOS-Chem \\
\hline Biofuel + fossil fuel & $20.6 \pm 0.16$ & $19.6 \pm 0.29$ \\
Biomass burning & $11.9 \pm 1.9$ & $11.9 \pm 2.0$ \\
Tropospheric chemical production & $42.3 \pm 0.92$ & $59.1 \pm 0.77$ \\
Source from methane oxidation & $30.3 \pm 0.95$ & $35.2 \pm 0.42$ \\
Loss with tropospheric OH & $77.7 \pm 2.1$ & $89.1 \pm 2.4$ \\
Net transport to stratosphere & $1.37 \pm 0.49$ & $1.50 \pm 0.47$ \\
\hline
\end{tabular}

resulting in 47 total layers. The simulation period is $2003-$ 2012, with January 2003 to April 2004 discarded as initialization. The model output data have a horizontal resolution of $2^{\circ}$ latitude $\times 2.5^{\circ}$ longitude, and 47 vertical layers between the surface and $0.01 \mathrm{hPa}$.

\subsubsection{Differences between GMI and GEOS-Chem}

To highlight the differences between the GMI and GEOSChem model run, we summarize their major differences in Table 1. In addition, we calculate the annual mean values and interannual standard deviations of $\mathrm{CO}$ budget (including biofuel and fossil fuel emissions, biomass burning emissions, tropospheric chemical production, tropospheric methane oxidation, loss with tropospheric $\mathrm{OH}$ and net transport from troposphere to stratosphere) for GMI and GEOS-Chem during the period 2004-2012, and the results are provided in Table 2. In general, $\mathrm{CO}$ emissions from fuel combustion and biomass burning are mostly the same, but the chemical production and loss rates of $\mathrm{CO}$ in the troposphere are quite different between the two models. Specifically, GEOS-Chem is 40,16 and $15 \%$ higher than GMI in tropospheric chemical production of $\mathrm{CO}$, tropospheric $\mathrm{CH} 4$ oxidation and $\mathrm{CO}$ loss with tropospheric $\mathrm{OH}$, respectively. For the net $\mathrm{CO}$ transport from troposphere to stratosphere, GEOS-Chem is $\sim 9.5 \%$ larger than GMI. 

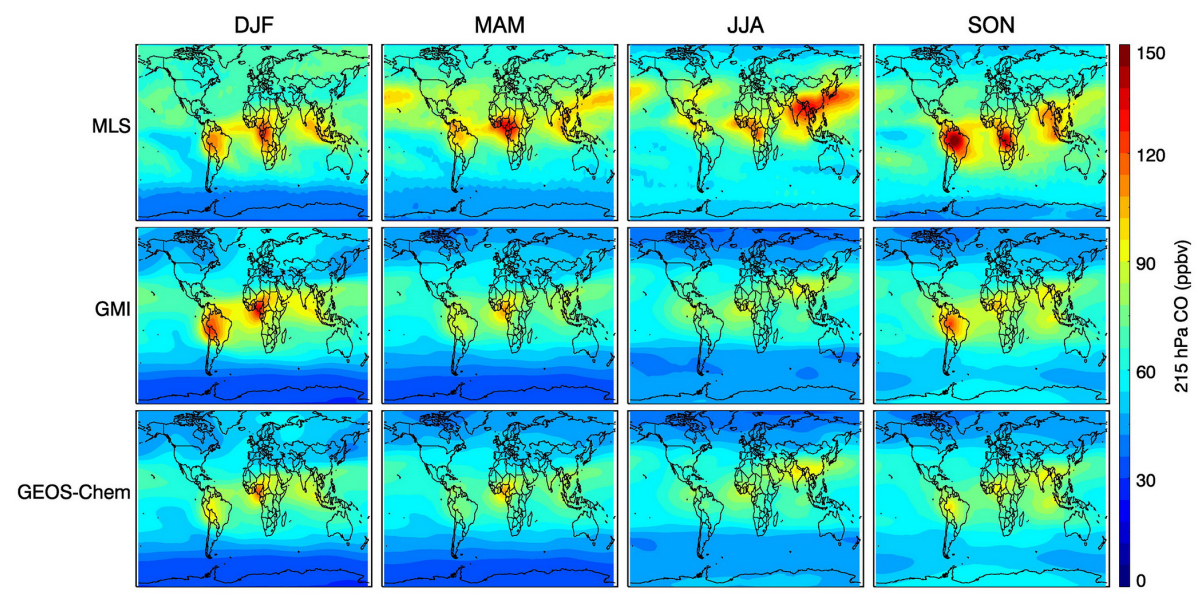

Figure 1. Seasonal mean (DJF, MAM, JJA and SON) distribution of CO mixing ratio at $215 \mathrm{hPa}$ for December 2004-November 2012 from (top row) MLS V4 data; (middle row) GMI model simulation with MLS averaging kernels (AKs) applied; (bottom row) GEOS-Chem model simulation with MLS AKs applied.

\subsubsection{Model/MLS comparison approach}

Both the GMI and GEOS-Chem simulations were archived at monthly temporal resolution, with the same horizontal resolution. GEOS-Chem provides model output on model levels whose pressure varies in time, whereas GMI provides output at fixed pressure levels. To compare the simulated and observed CO profiles, we first aggregate the daily Aura MLS along-track $\mathrm{CO}$ profiles into $2^{\circ}$ latitude $\times 2.5^{\circ}$ longitude grid boxes, and calculate monthly averages of $\mathrm{CO}$ in each grid box. We then apply the MLS V4.20 CO averaging kernels and a priori profiles to each model's simulated $\mathrm{CO}$ profiles to take into consideration the vertical sensitivity of the MLS retrieval for a most consistent comparison (Livesey et al., 2015). In this process, the modeled CO profiles are interpolated to the 37 pressure levels of the MLS retrieval.

\section{Global comparison between models and observation}

\subsection{Seasonal distributions of CO in the UTLS}

The climatological seasonal distributions of $\mathrm{CO}$ at $215 \mathrm{hPa}$ as observed by MLS and simulated by GMI and GEOSChem are shown in Fig. 1 (the differences between model simulations and MLS observation are shown in Fig. S1 in the Supplement). The seasonal average is calculated as the 8-year average from December 2004 to November 2012. In general, the locations of high $\mathrm{CO}$ are well simulated in GMI and GEOS-Chem versus the MLS observations, except over Africa. MLS indicates that local maxima occur over central Africa during DJF and southern Africa during SON (Huang et al., 2012), but the simulated maxima were over West Africa during both of these two seasons. The simulated $\mathrm{CO}$ values by both models are smaller than MLS observations, with an underestimation of generally less than $20 \%$ for the global mean $\left(80^{\circ} \mathrm{S}-80^{\circ} \mathrm{N}\right) \mathrm{CO}$ concentration (Table 3a). The largest underestimation occurs in MAM and JJA for both models, with GMI (GEOS-Chem) showing 20 (22.1) \% and 20.2 (19.5) \% less mean CO in MAM and JJA than MLS observations, respectively. Furthermore, peaks of simulated $\mathrm{CO}$ concentrations are smaller than MLS observations by up to $\sim 40 \%$ for all seasons. The trans-Pacific transport of CO from East Asia in MAM and JJA to North America is shown in the model simulations, but the $\mathrm{CO}$ concentrations are $\sim 30 \%$ lower than the observations. Continental outflow of $\mathrm{CO}$ in the UT from the eastern United States and West Africa to the Atlantic Ocean during JJA is also poorly simulated by both models. The simulated CO distribution of GMI is quite similar to that of GEOS-Chem (the correlation coefficient between the two maps for each season is greater than 0.98), with the difference of mean $\mathrm{CO}$ less than $7 \%$ (Table 3a). The mean and peak values of simulated $\mathrm{CO}$ in GEOS-Chem are generally less than those from GMI at this level, especially over South America and Africa during DJF and SON (CO peak in GEOS-Chem is $\sim 20 \%$ less than that in GMI).

At $147 \mathrm{hPa}$, high CO concentrations are mainly found in the tropical and subtropical latitudes, especially over South America and Africa (Figs. 2 and S2). During boreal summer, there is a broad maximum over South Asia driven by convection associated with the Asian summer monsoon (Fu et al., 2006; Park et al., 2009; Randel et al., 2010). However, this maximum in model simulations is not as broad as in the MLS observations. In addition, both models underestimate $\mathrm{CO}$ concentrations poleward of $50^{\circ}$. The underestimation is generally less than $32 \%$ for the global mean CO concentration (Table $3 \mathrm{~b}$ ), with the largest underestimation occurring in MAM for both models (32.4\% for GMI, $31.5 \%$ for GEOS-Chem). In addition, seasonal $\mathrm{CO}$ maxima are also underestimated by about $30-40 \%$ in the tropics. The difference 
Table 3. Statistical comparison of model-simulated and MLS-observed (V4) CO at (a) $215 \mathrm{hPa}$, (b) $147 \mathrm{hPa}$ and (c) $100 \mathrm{hPa}$ during each season.

\begin{tabular}{|c|c|c|c|c|c|c|c|c|c|c|c|c|c|}
\hline \multirow{3}{*}{ Level } & \multirow{3}{*}{ Season } & & & & \multicolumn{9}{|c|}{ Model biases (\%) } \\
\hline & & \multicolumn{3}{|c|}{ Correlation } & \multicolumn{3}{|c|}{ Maximum difference } & \multicolumn{3}{|c|}{ Minimum difference } & \multicolumn{3}{|c|}{ Mean difference } \\
\hline & & $\begin{array}{l}\stackrel{+}{>} \\
\sum_{0}^{\infty} \\
\dot{D}\end{array}$ & 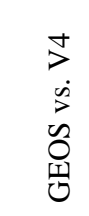 & $\begin{array}{l}\mathscr{O} \\
0 \\
\text { II } \\
\dot{\infty} \\
\sum_{0}\end{array}$ & 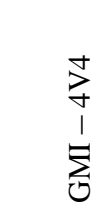 & 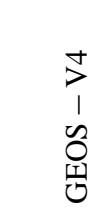 & $\begin{array}{l}\sum_{0} \\
1 \\
\text { 1 } \\
0 \\
\text { I0 } \\
0\end{array}$ & $\stackrel{+}{\sum_{0}^{+}}$ & $\begin{array}{c}\underset{>}{+} \\
1 \\
\infty \\
0 \\
0 \\
0\end{array}$ & $\begin{array}{l}\sum_{0} \\
1 \\
1 \\
0 \\
0 \\
\mathbb{0}\end{array}$ & $\frac{+}{\sum_{0}^{+}}$ & $\begin{array}{c}\stackrel{+}{>} \\
1 \\
\sim \\
0 \\
0 \\
0 \\
0\end{array}$ & $\begin{array}{l}\sum_{0} \\
1 \\
0 \\
0 \\
0 \\
\mathbb{1}\end{array}$ \\
\hline \multirow[t]{4}{*}{ (a) $215 \mathrm{hPa}$} & DJF & 0.89 & 0.90 & 0.990 & -39.0 & -40.8 & -21.4 & 30.7 & 14.5 & 3.2 & -10.5 & -16.6 & -6.8 \\
\hline & MAM & 0.90 & 0.90 & 0.995 & -36.6 & -37.9 & -12.1 & 7.50 & 4.1 & 4.1 & -20.0 & -22.1 & -2.7 \\
\hline & JJA & 0.83 & 0.85 & 0.993 & -40.3 & -39.9 & -6.8 & 13.7 & 9.9 & 8.9 & -20.2 & -19.5 & 0.8 \\
\hline & SON & 0.85 & 0.82 & 0.983 & -43.5 & -47.9 & -19.9 & 44.3 & 45.1 & 4.3 & -11.1 & -14.5 & -3.8 \\
\hline \multirow[t]{4}{*}{ (b) $147 \mathrm{hPa}$} & DJF & 0.92 & 0.93 & 0.996 & -61.7 & -60.0 & -17.4 & 6.4 & -2.1 & 5.6 & -27.5 & -29.1 & -2.2 \\
\hline & MAM & 0.96 & 0.95 & 0.998 & -59.7 & -59.2 & -7.0 & -6.6 & -5.5 & 6.5 & -32.4 & -31.5 & 1.3 \\
\hline & JJA & 0.96 & 0.97 & 0.997 & -53.8 & -52.0 & -1.9 & -4.4 & -5.6 & 15.6 & -31.3 & -27.8 & 5.2 \\
\hline & SON & 0.96 & 0.96 & 0.996 & -50.0 & -47.9 & -13.7 & 5.0 & 6.2 & 10.3 & -25.2 & -24.1 & 1.4 \\
\hline \multirow[t]{4}{*}{ (c) $100 \mathrm{hPa}$} & DJF & 0.93 & 0.94 & 0.999 & -70.2 & -68.4 & -3.2 & -21.9 & -21.9 & 8.4 & -46.1 & -43.9 & 4.0 \\
\hline & MAM & 0.97 & 0.97 & 0.999 & -64.1 & -63.0 & 1.0 & -29.8 & -27.1 & 10.0 & -47.8 & -44.8 & 5.6 \\
\hline & JJA & 0.92 & 0.93 & 0.998 & -67.9 & -66.4 & 1.4 & -23.7 & -18.6 & 20.1 & -47.4 & -42.8 & 8.7 \\
\hline & SON & 0.97 & 0.97 & 0.997 & -61.7 & -60.0 & -0.6 & -22.0 & -18.0 & 14.6 & -44.7 & -40.6 & 7.5 \\
\hline
\end{tabular}
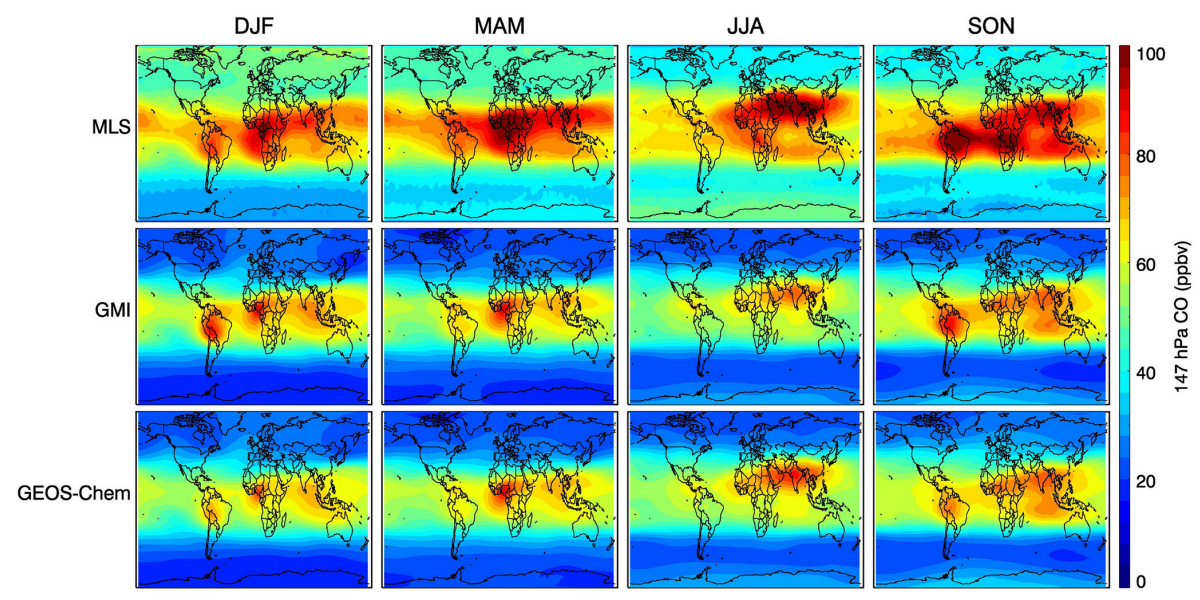

Figure 2. As in Fig. 1, but for CO mixing ratio at $147 \mathrm{hPa}$.

in mean $\mathrm{CO}$ concentration between the two model simulations is generally less than $5 \%$, with GEOS-Chem slightly larger than GMI during all seasons except DJF (Table 3b). Maxima over South America and West Africa during SON and DJF are greater in magnitude $(\sim 15 \%)$ in GMI than in GEOS-Chem, but the latter shows a greater maximum ( $\sim 9 \%$ ) over South Asia during JJA than the former. The largest model-observation discrepancies occur at $100 \mathrm{hPa}$ as shown in Fig. 3 (and Fig. S3). Both models significantly underestimate the observed CO concentrations (note the different color scales in Fig. 3) compared to MLS. The underestimation is larger than $40 \%$ for the global mean CO concentra- tion (Table 3c), with the largest underestimation occurring in MAM for both models (47.8\% for GMI, $44.8 \%$ for GEOSChem). Although the simulations generally capture the local maxima and minima in each season, the magnitudes are significantly smaller than the observation. The underestimation of $\mathrm{CO}$ extremes from GMI ranges from $\sim 22$ to $\sim 70 \%$ compared with MLS CO, while the underestimation from GEOSChem ranges $\sim 18-68 \%$. Both model simulations show similar CO distributions to each other, but the CO maxima in GMI are generally smaller than those in GEOS-Chem, with a maximum difference of $\sim 8.7 \%$ during JJA for the global mean CO (Table 3c). 


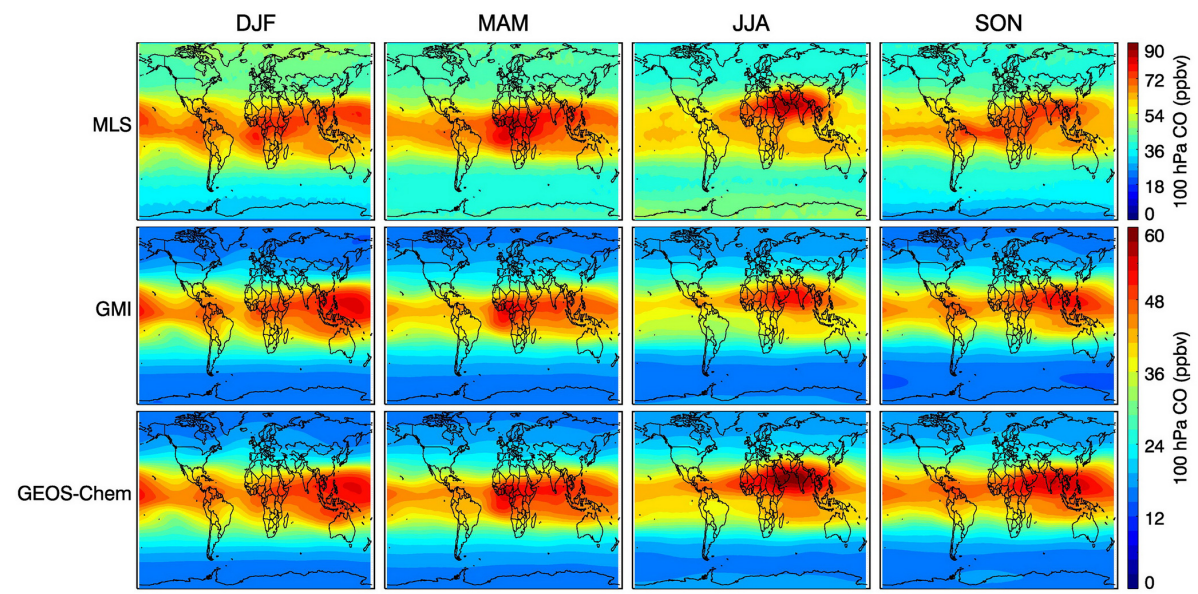

Figure 3. As in Fig. 1, but for CO mixing ratio at $100 \mathrm{hPa}$.
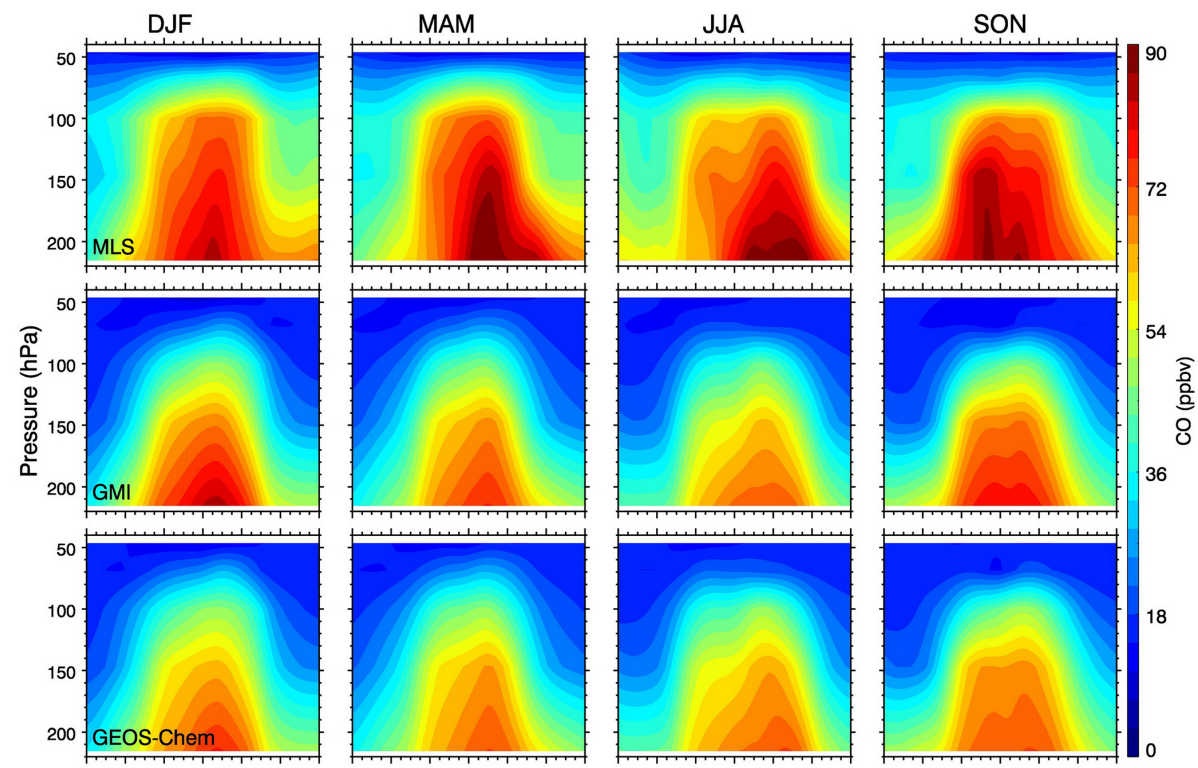

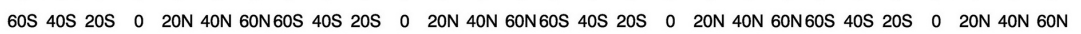

Figure 4. Vertical/latitudinal distribution of zonal mean CO mixing ratio during different seasons (DJF, MAM, JJA and SON) from (top row) MLS V4 data; (middle row) GMI model simulation with MLS AKs applied; (bottom row) GEOS-Chem model simulation with MLS AKs applied.

The vertical distribution of zonal mean $\mathrm{CO}$ and its seasonal variations are shown in Fig. 4 (and Fig. S4). In general, MLS CO shows a pipe-like maximum in the tropics from 200 to $100 \mathrm{hPa}$, with a stronger vertical gradient above $100 \mathrm{hPa}$ than below. However, the simulations have more diffuse horizontal gradients in the UT and the vertical gradient of $\mathrm{CO}$ is stronger below $100 \mathrm{hPa}$ and weaker above $100 \mathrm{hPa}$ than MLS. This may suggest that upward transport of $\mathrm{CO}$ is underestimated in the models. The average model bias (model CO minus MLS CO and then divided by MLS CO, same hereinafter) is -24 to $-27 \%$ for GMI and -23 to $-24 \%$ for GEOS-Chem throughout the year. The maximum model bias is $-64 \%$ for GMI and $-63 \%$ for GEOS-Chem. Although the models successfully reproduce a seasonal shift of local UT maxima from the tropics to the northern subtropics from DJF to JJA, they fail to simulate the higher maxima in the southern subtropics during SON. This is mainly due to the underestimation of $\mathrm{CO}$ concentration in the UT over southern Africa and South America (Figs. 1 and 2). The two models' simulations are quite similar (correlation coefficient > 0.996), except for some differences in magnitude below (i.e., at pressures greater than) $150 \mathrm{hPa}$ during SON and DJF as previously shown in the $\mathrm{CO}$ distribution map (Fig. 1). 


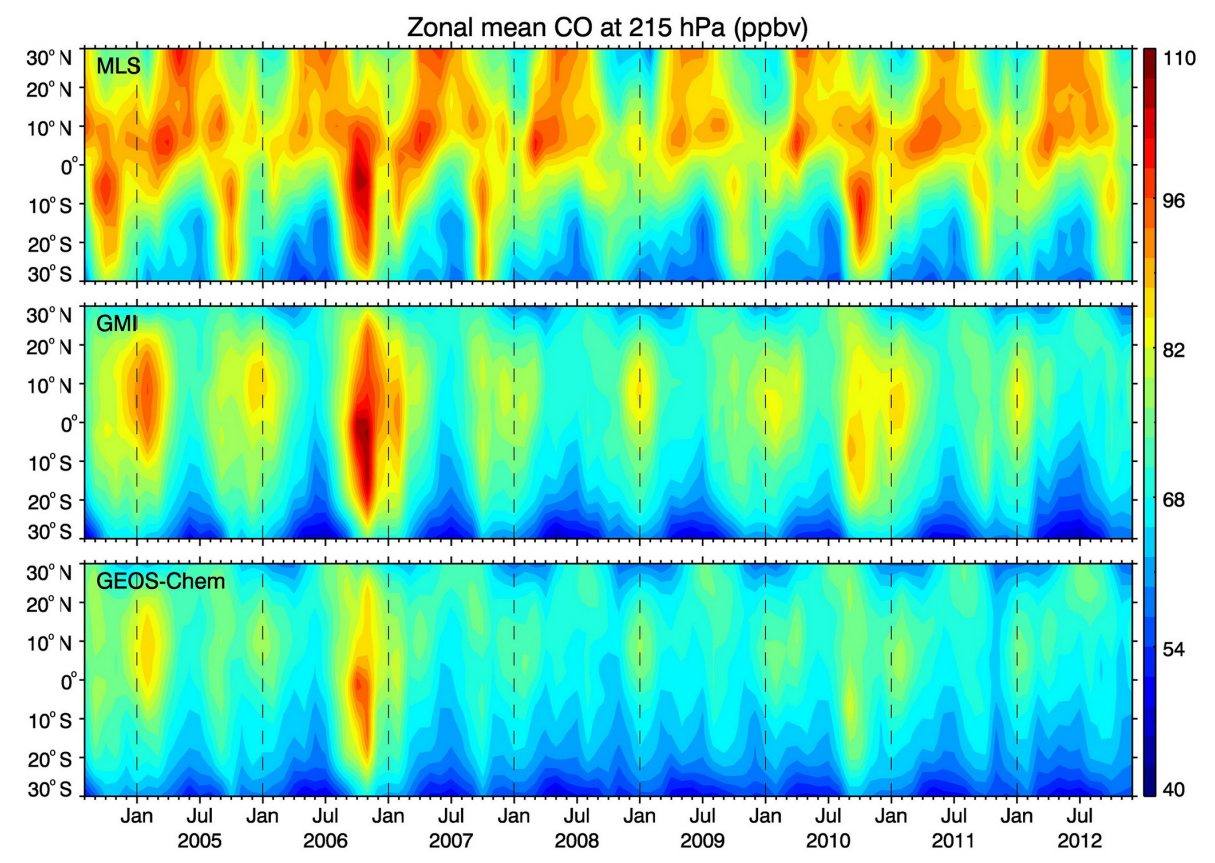

Figure 5. Monthly variation of zonal mean CO mixing ratio at $215 \mathrm{hPa}$ for August 2004-December 2012 from (top row) MLS V4 data; (middle row) GMI model simulation with MLS AKs applied; (bottom row) GEOS-Chem model simulation with MLS AKs applied.

\subsection{Monthly variations of $\mathrm{CO}$ in the UTLS}

The temporal variability of the zonal mean monthly $\mathrm{CO}$ from $30^{\circ} \mathrm{S}$ to $30^{\circ} \mathrm{N}$ at $215 \mathrm{hPa}$ for more than 8 years (August 2004-December 2012) is shown in Fig. 5 (and Fig. S5). The high $\mathrm{CO}$ concentrations observed in the northern tropics and subtropics are underestimated in the models, especially from April to July when both models underestimate by as much as $33 \%$, which is significant compared to the MLS measurement uncertainty. This is mainly due to the underestimated $\mathrm{CO}$ over South Asia and East Asia, as well as the eastern United States and downwind regions as shown in Fig. 1. As a consequence, the seasonal cycle of $\mathrm{CO}$ over this latitudinal band is not well simulated. The temporal variation of $\mathrm{CO}$ in the southern subtropics is well captured by GMI ( $r=0.83, n=15$ latitudes $\times 101$ months $)$ and GEOS-Chem $(r=0.80)$, except that the magnitude is a little smaller than in the observation (difference $<10 \%$ ). High $\mathrm{CO}$ values simulated by GMI during El Niño-Southern Oscillation (ENSO) periods are comparable with MLS CO (difference is 2-11\%), which is mainly related to stronger $\mathrm{CO}$ emissions generated by drought-induced fires in Indonesia or South America compared to normal years (Liu et al., 2013; Livesey et al., 2013; Huang et al., 2014). The maximum model bias at this level is $-34 \%$ for GMI and $-33 \%$ for GEOS-Chem, while the mean model bias is $-9 \%$ (GMI) and $-14 \%$ (GEOS-Chem). GMI shows higher $\mathrm{CO}$ values in the tropics during DJF and SON than GEOS-Chem (difference is still within $10 \%$ ), especially in some ENSO years such as 2004-2005, 2006-2007 and 2010-2011. The comparisons of zonal mean CO between
MLS and models at $147 \mathrm{hPa}$ are similar to $215 \mathrm{hPa}$ (figure not shown). At $100 \mathrm{hPa}$ (Figs. 6 and S6), the most distinctive feature is the semi-annual peaks with similar magnitudes in boreal spring and fall as shown in MLS data. This semi-annual variation of $\mathrm{CO}$ in the UT is mainly due to the temporal overlapping of surface biomass burning from different continents and the interhemispheric shifts of deep convection (Duncan et al., 2007; Liu et al., 2013). The two models significantly underestimate $\mathrm{CO}$ at this level, and the peak during MAM is much weaker than the other peak during SON. The model bias ranges from -54 to $-22 \%$ for GMI and from -48 to $-13 \%$ for GEOS-Chem. The semi-annual CO peaks during boreal spring and fall in GEOS-Chem are slightly $(\sim 5 \%)$ larger than those in GMI.

Figure 7 shows the temporal evolution of monthly meridional mean tropical $\left(15^{\circ} \mathrm{S}-15^{\circ} \mathrm{N}\right) \mathrm{CO}$ at $215 \mathrm{hPa}$ (also see Fig. S7). In general, GMI shows better agreement with MLS observation than GEOS-Chem with respect to the locations and magnitudes of the high $\mathrm{CO}$ concentration, since the magnitudes of CO peaks are $14 \%$ weaker in GEOS-Chem than in GMI. The correlation coefficients between observation and simulations are 0.78 and 0.81 for GMI and GEOS-Chem, respectively ( $n=144$ longitudes $\times 101$ months). The seasonal peaks over South America, Africa and Indonesia are well represented in the model simulations, but their magnitudes are smaller than those observed, especially over Africa and Indonesia (maximum bias is $-42 \%$ for GMI and $-51 \%$ for GEOS-Chem). The maxima ( 160-170 ppbv) over Indonesia during 2006-2007 El Niño are well captured by the models (difference between model and observation $<5 \%$ ). 


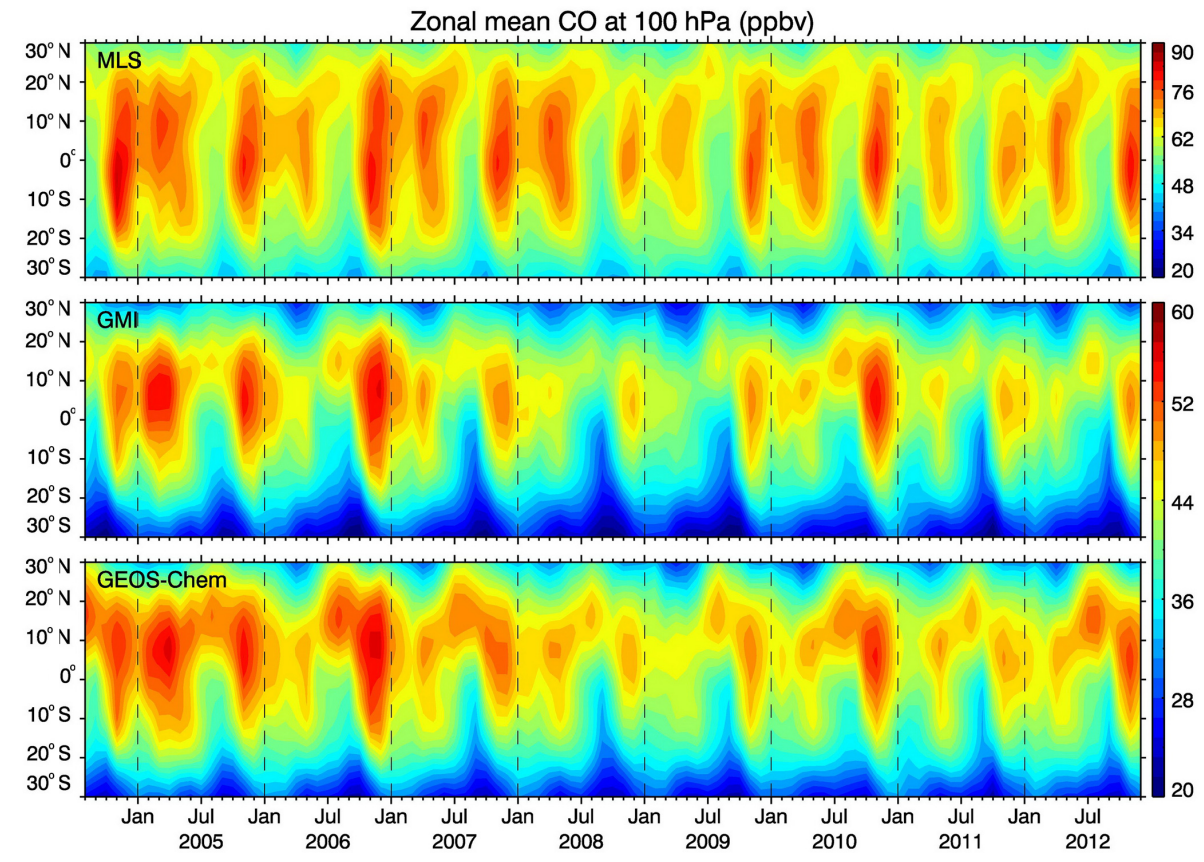

Figure 6. As in Fig. 5, but for CO mixing ratio at $100 \mathrm{hPa}$.

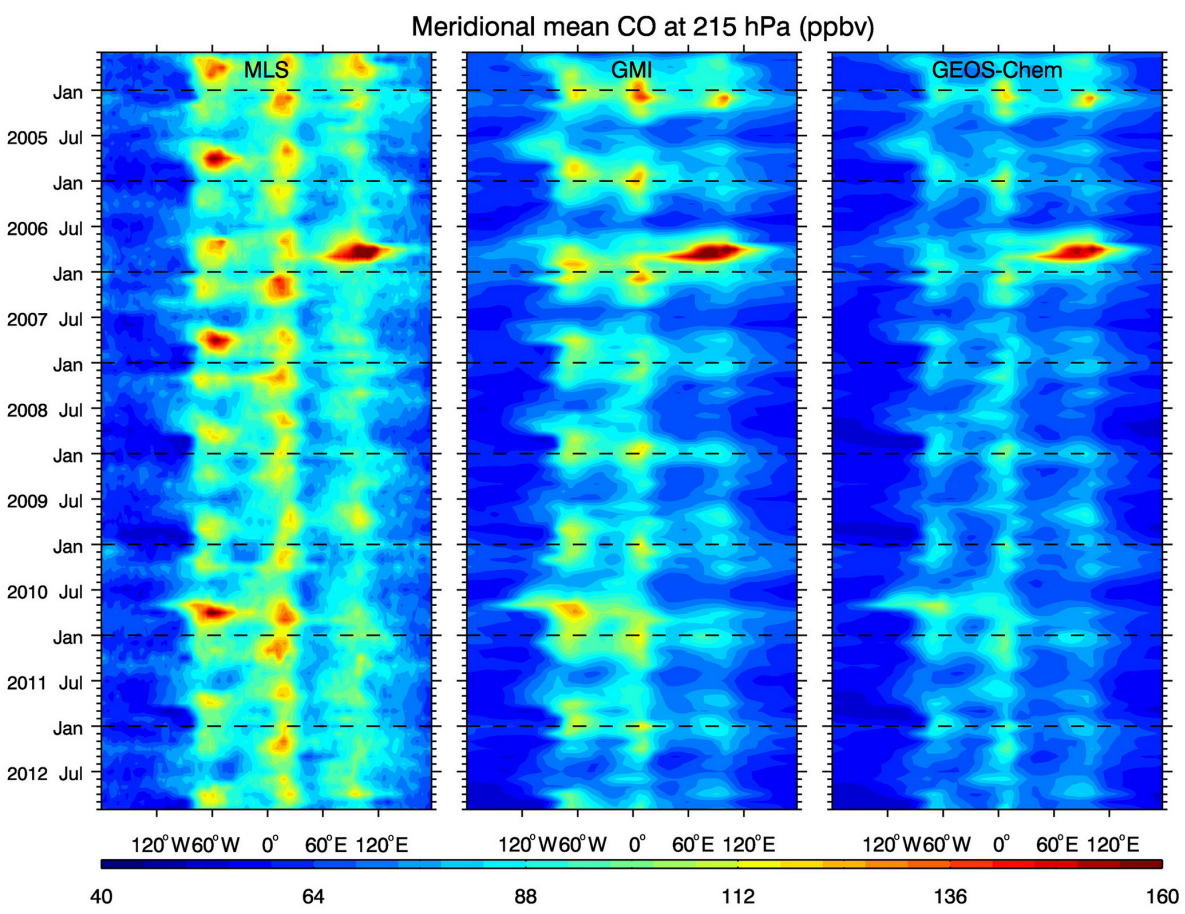

Figure 7. Monthly variation of meridional mean $\left(15^{\circ} \mathrm{S}-15^{\circ} \mathrm{N}\right) \mathrm{CO}$ mixing ratio at $215 \mathrm{hPa}$ for August 2004-December 2012 from (left) MLS V4 data; (middle) GMI model simulation with MLS AKs applied; (right) GEOS-Chem model simulation with MLS AKs applied.

At $147 \mathrm{hPa}$ (figure not shown), the interannual variation of meridional mean $\mathrm{CO}$ is similar to that at $215 \mathrm{hPa}$, except that the seasonal high $\mathrm{CO}$ encompasses a larger zonal area. At $100 \mathrm{hPa}$, the consistency between the models and MLS is substantially worse, as indicated by the significant un- derestimation $(>50 \%)$ of $\mathrm{CO}$ peaks and the locations of seasonal CO maxima (Figs. 8 and S8). For example, MLS shows a local CO maximum ( $\sim 90 \mathrm{ppbv})$ over Africa during November-December 2007 that the simulations do not capture. Furthermore, MLS detects clear semi-annual CO peaks 


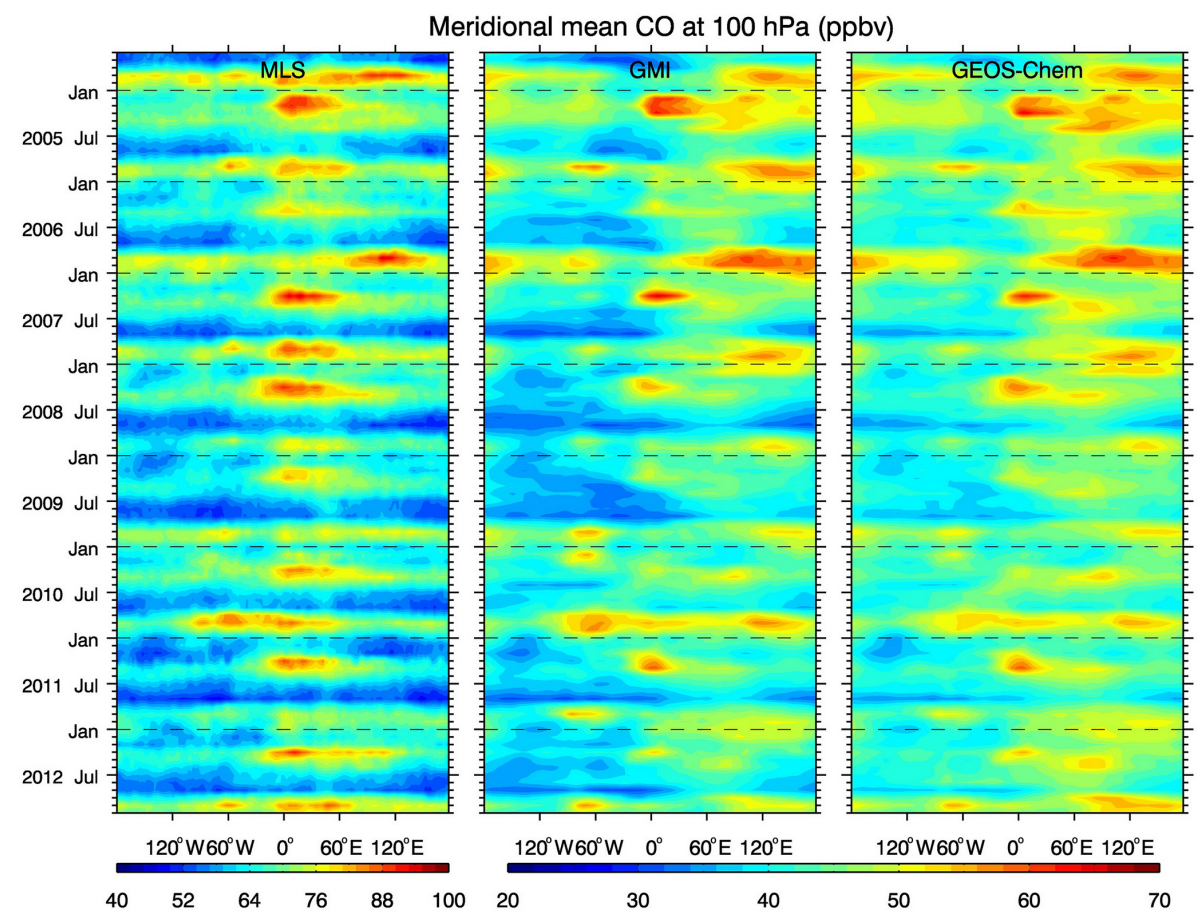

Figure 8. As in Fig. 7, but for CO mixing ratio at $100 \mathrm{hPa}$.

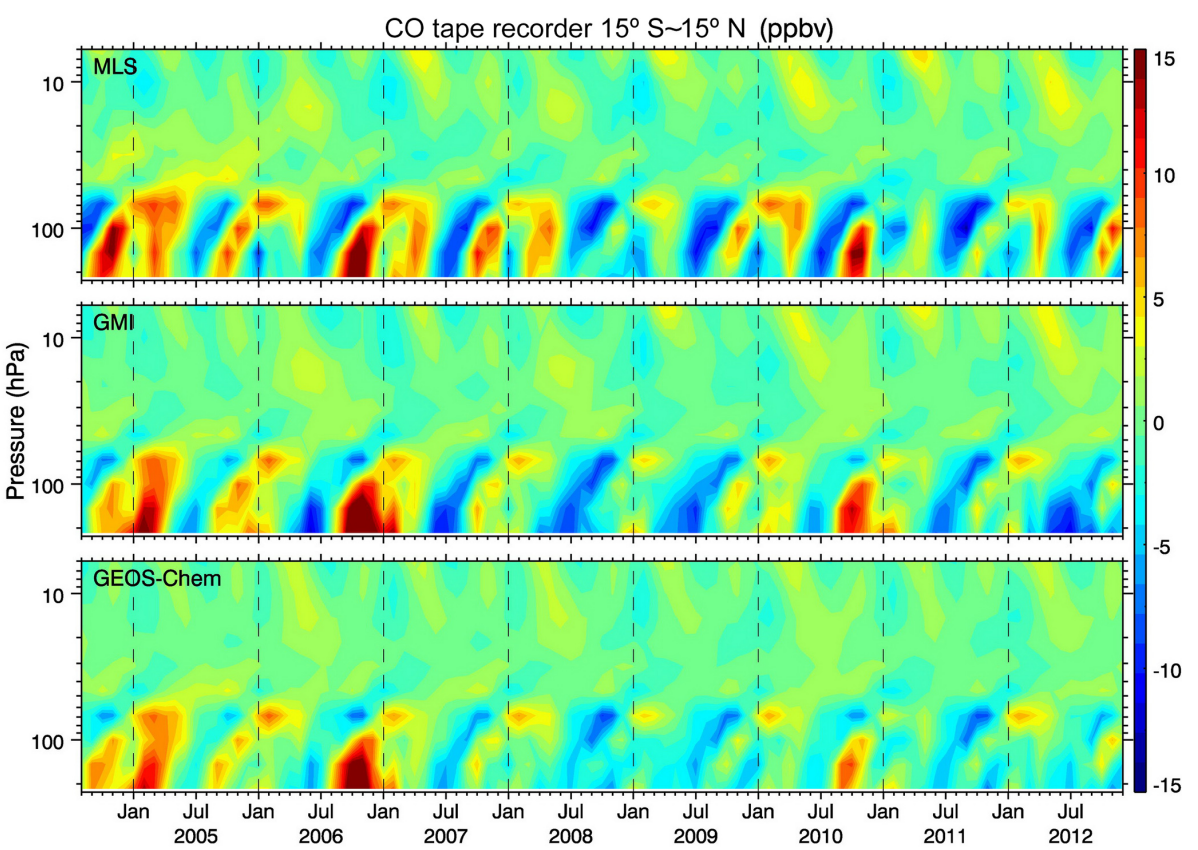

Figure 9. Temporal variation of monthly mean CO deviations, zonally averaged over the tropics $\left(15^{\circ} \mathrm{S}-15^{\circ} \mathrm{N}\right)$, vertically from 200 to $50 \mathrm{hPa}$ for August 2004-December 2012 from (top row) MLS V4 data; (middle row) GMI model simulation with MLS AKs applied; (bottom row) GEOS-Chem model simulation with MLS AKs applied. An 8-year mean (2005-2012) was subtracted from the monthly mean time series at each level for MLS data and the two models' simulations.

over Africa, but the models only show one annual peak. The correlation coefficients between observation and simulations are also reduced to 0.74 . Overall, the average magnitude of
$\mathrm{CO}$ in GEOS-Chem is $\sim 5 \%$ larger than that in GMI at this level. 


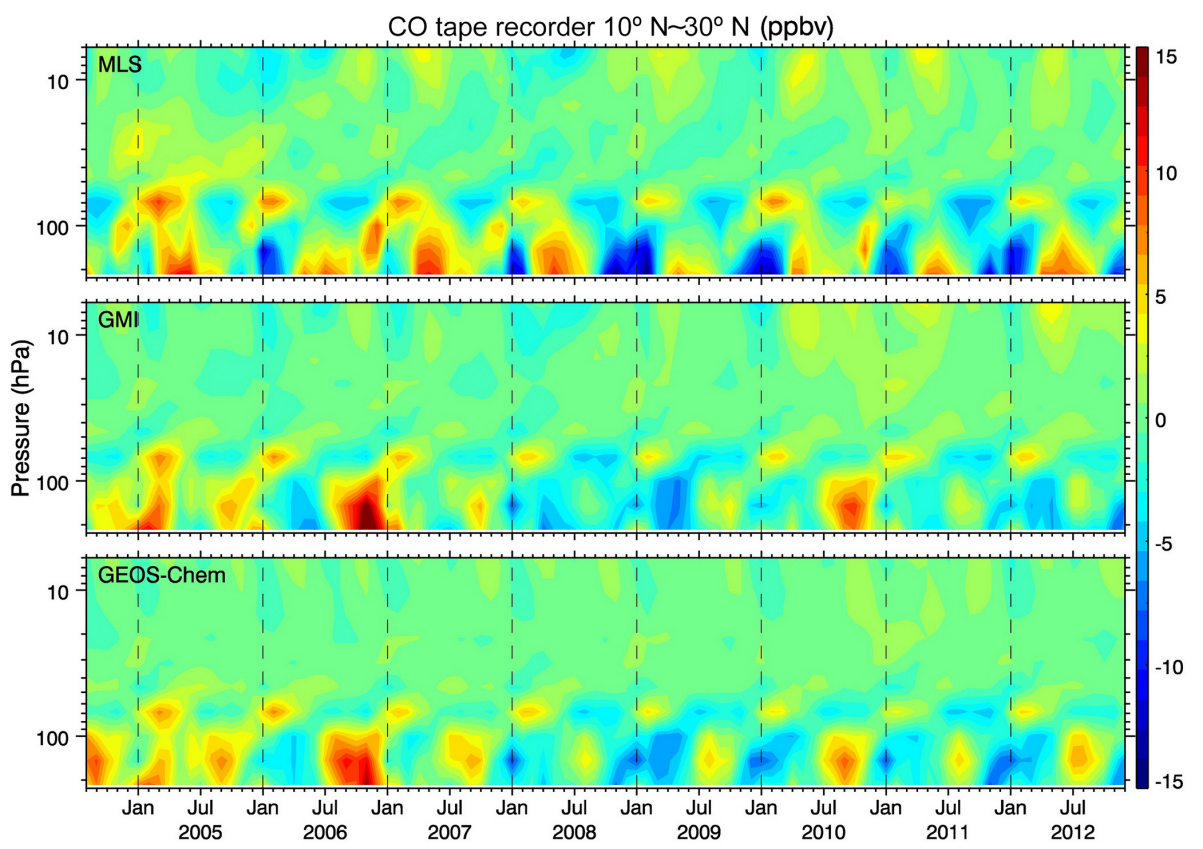

Figure 10. As in Fig. 9, but over the northern subtropics $\left(10^{\circ}-30^{\circ} \mathrm{N}\right)$.

\subsection{CO tape recorder}

Air masses can enter the stratosphere in the tropics, driven by adiabatic upwelling of the Brewer-Dobson circulation (Brewer, 1949). During this slow upward transport, seasonal and interannual variations in the mixing ratios of some trace gases are preserved, as first observed in water vapor by Mote et al. (1995). This phenomenon is termed the tape recorder. Schoeberl et al. (2006) identified the CO tape recorder for the first time using MLS observations from August 2004 to December 2005. In this study, we evaluate the model-simulated CO tape recorder by taking advantage of the multiyear MLS data now available. Figure 9 shows the $\mathrm{CO}$ tape recorder over the tropics (as a zonal mean between $15^{\circ} \mathrm{S}$ and $15^{\circ} \mathrm{N}$ ). An 8 -year mean (2005-2012) was subtracted from the monthly mean time series at each level for MLS data and the two models' simulations. The differences of CO tape recorder between MLS observation and model simulations are shown in Fig. S9. In general, the observed and simulated CO tape recorders show good agreement ( $r=0.76$ for GMI, $r=0.81$ for GEOS-Chem, $n=11$ levels $\times 101$ months). The observations and simulations show a semi-annual cycle around $200 \mathrm{hPa}$ and a strong annual cycle above $80 \mathrm{hPa}$. In the lower stratosphere, both models show that the tape recorder signal fades out at approximately the same altitude $(\sim 50 \mathrm{hPa}$ or $20 \mathrm{~km}$ ) and the phase lines are quite similar to MLS observations. In the upper troposphere, the two models simulate the interannual variation of $\mathrm{CO}$ during the Northern and Southern Hemisphere fire seasons, which suggests that the surface $\mathrm{CO}$ emissions account for most of the $\mathrm{CO}$ variation near the tropopause. The phase shift and $\mathrm{CO}$ anomaly mag- nitude in GMI simulation are more consistent with MLS observation than those in GEOS-Chem simulation. For example, the average difference of positive $\mathrm{CO}$ anomaly between GMI and MLS is $15 \%$, while that for GEOS-Chem is $32 \%$. The models show that the location of the "tape head" is near $200 \mathrm{hPa}$, which is in rough agreement with MLS. In addition, the strong positive $\mathrm{CO}$ anomalies during three ENSO years (2004-2005, 2006-2007 and 2010-2011) are captured by both observation and models.

The CO tape recorder signal over northern subtropics (10$30^{\circ} \mathrm{N}$ ) is shown in Fig. 10 (also see Fig. S10). In general, model-simulated tape recorders are not consistent with observation, as shown by a $2-3$ month time lag between the same phases of $\mathrm{CO}$ peak anomaly. This inconsistency may be caused by the underestimation of vertical transport in the models (Schoeberl et al., 2006; Liu et al., 2010). Over this region, the ENSO signal is not as strong in the MLS observations as that over the tropics; yet the two models still show high positive $\mathrm{CO}$ anomalies during several ENSO periods. For the southern subtropics $\left(10-30^{\circ} \mathrm{S}\right)$, MLS and models have much better agreement (Figs. 11 and S11). The seasonal peaks and phase shift of $\mathrm{CO}$ anomalies are well collocated between observation and simulations. GMI simulation is much closer to MLS observation than GEOS-Chem in magnitude. For example, the difference of positive $\mathrm{CO}$ anomaly between GMI and MLS is within $31 \%$, while that for GEOS-Chem is within $48 \%$. However, the magnitude of positive anomaly in GMI simulation is still smaller than MLS observation (except the 2006-2007 El Niño year), which is mainly due to the underestimation of surface $\mathrm{CO}$ emission 


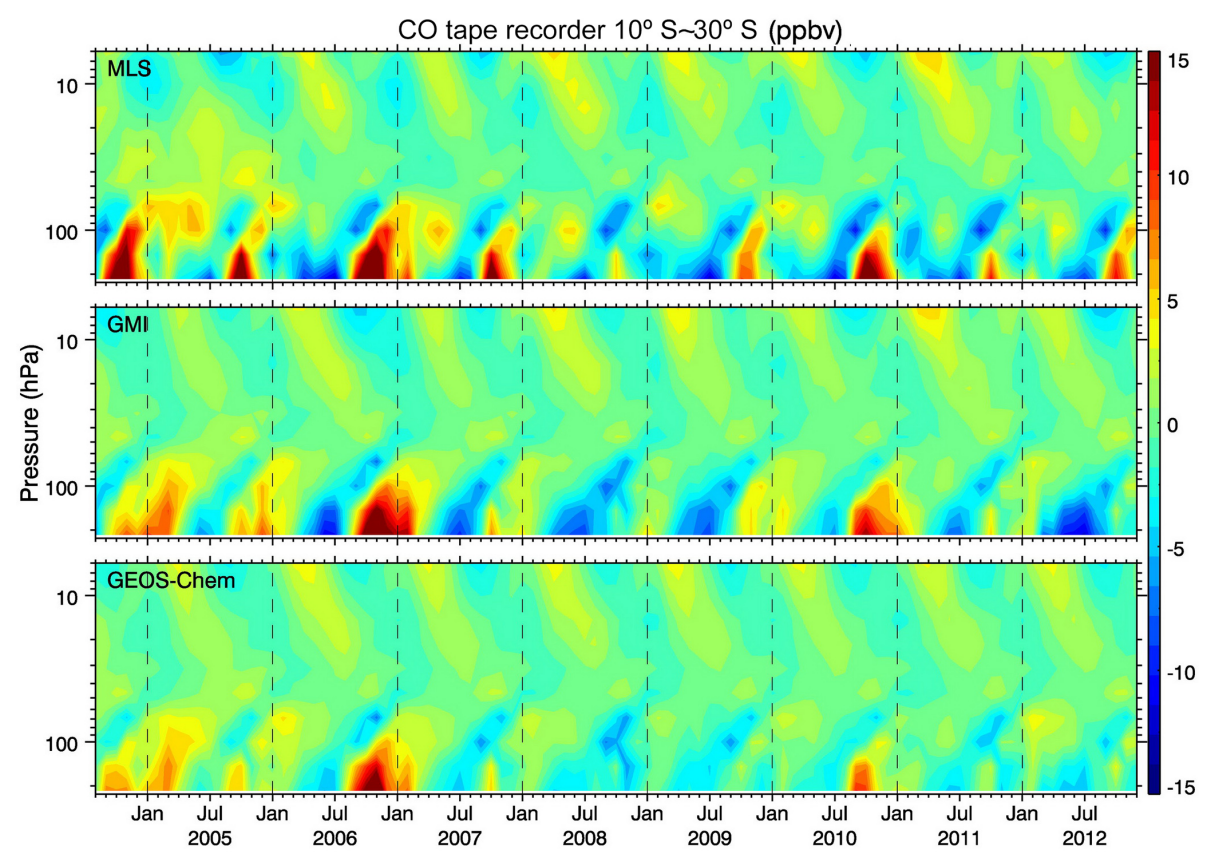

Figure 11. As in Fig. 9, but over the southern subtropics $\left(10^{\circ}-30^{\circ} \mathrm{S}\right)$.

over South America and southern Africa (Liu et al., 2010, 2013).

\section{Regional comparison between models and observation}

To further evaluate $\mathrm{CO}$ differences between observation and model simulations, we examine six regions of high $\mathrm{CO}$ : South America $\left(0-30^{\circ} \mathrm{S}, 40-80^{\circ} \mathrm{W}\right)$, southern Africa $(0$ $\left.30^{\circ} \mathrm{S}, 10-40^{\circ} \mathrm{E}\right)$, northern Africa $\left(0-30^{\circ} \mathrm{N}, 15^{\circ} \mathrm{W}-40^{\circ} \mathrm{E}\right)$, East Asia $\left(20-45^{\circ} \mathrm{N}, 105-145^{\circ} \mathrm{E}\right)$, South Asia $\left(10-30^{\circ} \mathrm{N}\right.$, $\left.70-105^{\circ} \mathrm{E}\right)$ and Indonesia $\left(10^{\circ} \mathrm{S}-10^{\circ} \mathrm{N}, 100-150^{\circ} \mathrm{E}\right)$.

\subsection{Monthly variations of $\mathrm{CO}$ in the UTLS}

Figure 12 shows the climatological monthly mean of CO at $215 \mathrm{hPa}$ from MLS and the models over these regions. Both models underestimate the $\mathrm{CO}$ seen by the observations throughout the year over three regions (southern Africa, East Asia and Indonesia). The largest underestimation for a month by GMI (GEOS-Chem) is 19 (33) \% over South America, 30 (36) \% over southern Africa, 22 (23) \% over northern Africa, 37 (35) \% over East Asia, 31 (29)\% over South Asia and 22 (22) \% over Indonesia. The seasonal cycle of CO is similar between MLS and the models over South America $(r=$ 0.81 for both models), southern Africa ( $r=0.74$ for GMI, $r=0.75$ for GEOS-Chem) and Indonesia ( $r=0.92$ for GMI, $r=0.95$ for GEOS-Chem) (Fig. 12a, b, and f), although the magnitudes are underestimated. Over these first two regions, MLS shows maxima in October; both models greatly under- estimate the peak value and fail to simulate the observed decreasing trend from October to January. Over Indonesia, there is an average underestimation of $\sim 15 \%$ throughout the year. The underestimation of $\mathrm{CO}$ peaks over these regions may be due to low biases in direct surface emission, the fraction of fire emissions released above the boundary layer, biogenic NMVOC oxidation and/or upward convective transport. Over the other three regions, simulated seasonal variations are not consistent with MLS. For example, MLS shows CO peaks in July for East Asia and in August for South Asia (Fig. 12d and e), but the peaks in both models lag MLS by 1 month. This is probably due to insufficient representation of vertical transport in the CTMs or underlying meteorological reanalysis. CO mixing ratios simulated by GMI are generally larger than by GEOS-Chem, with differences typically less than $10 \%$. However, the model differences are larger from October to February over South America and Africa, with a maximum of $\sim 20 \%$ (Fig. 12a-c).

At $147 \mathrm{hPa}$, the differences in $\mathrm{CO}$ are similar to those at $215 \mathrm{hPa}$ (figure not shown). Compared with MLS, the largest underestimation by GMI (GEOS-Chem) is 26 (32)\% over South America, 35 (35) \% over southern Africa, 28 (27) \% over northern Africa, 33 (32) \% over East Asia, 28 (25) \% over South Asia and 19 (18)\% over Indonesia. The differences in CO at $100 \mathrm{hPa}$ between MLS and the models are shown in Fig. 13. The seasonal cycles are similar between MLS and models over South America, southern Africa and Indonesia (Fig. 13a, b and f), but large discrepancies exist over northern Africa and South Asia (Fig. 13c and e). The underestimation by the models reaches a maximum at this 

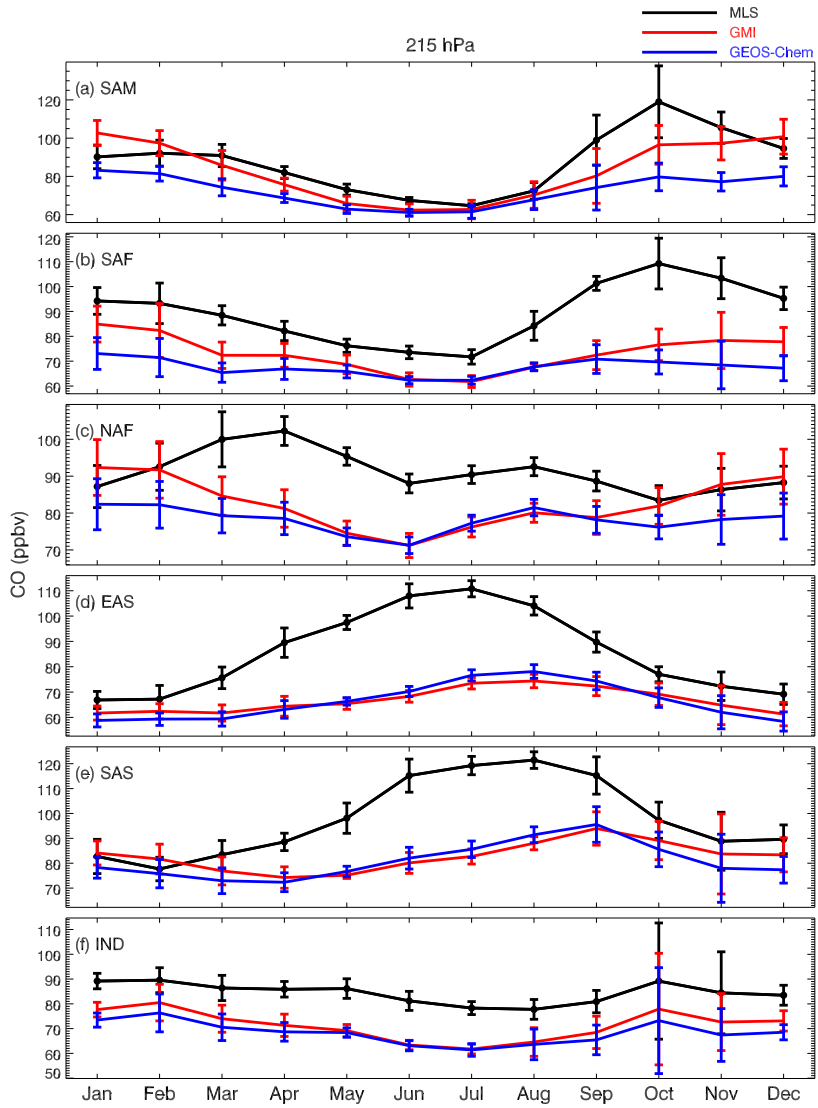

Figure 12. Climatological (8-year) monthly mean of CO mixing ratio at $215 \mathrm{hPa}$ from MLS V4 data (black line), GMI model simulation with MLS AKs applied (red line) and GEOS-Chem model simulation with MLS AKs applied (blue line) over the selected six regions: (a) South America, (b) southern Africa, (c) northern Africa, (d) East Asia, (e) South Asia and (f) Indonesia. The error bars indicate \pm 1 interannual standard deviation of the monthly mean $\mathrm{CO}$ from MLS observation and model simulations.

level. For example, the largest underestimation by GMI is $46 \%$ over South America, $46 \%$ over southern Africa, $41 \%$ over northern Africa, $46 \%$ over East Asia, $42 \%$ over South Asia and $36 \%$ over Indonesia, compared with MLS. In general, the temporal variations of GMI and GEOS-Chem are similar, but GMI is smaller than GEOS-Chem over all regions, especially from May to October.

\subsection{Vertical profiles of $\mathrm{CO}$ in the UTLS}

To evaluate the vertical distribution of CO in the UTLS, we present 8-year seasonal mean $\mathrm{CO}$ profiles for each region (Fig. 14). Both models underestimate $\mathrm{CO}$ at all levels observed by MLS below (i.e., with pressures greater than) $50 \mathrm{hPa}$. The magnitude of underestimation depends on region, altitude and season. For instance, the difference between MLS and GMI CO during JJA increases monotonically from 215 to $100 \mathrm{hPa}$ over South America, whereas

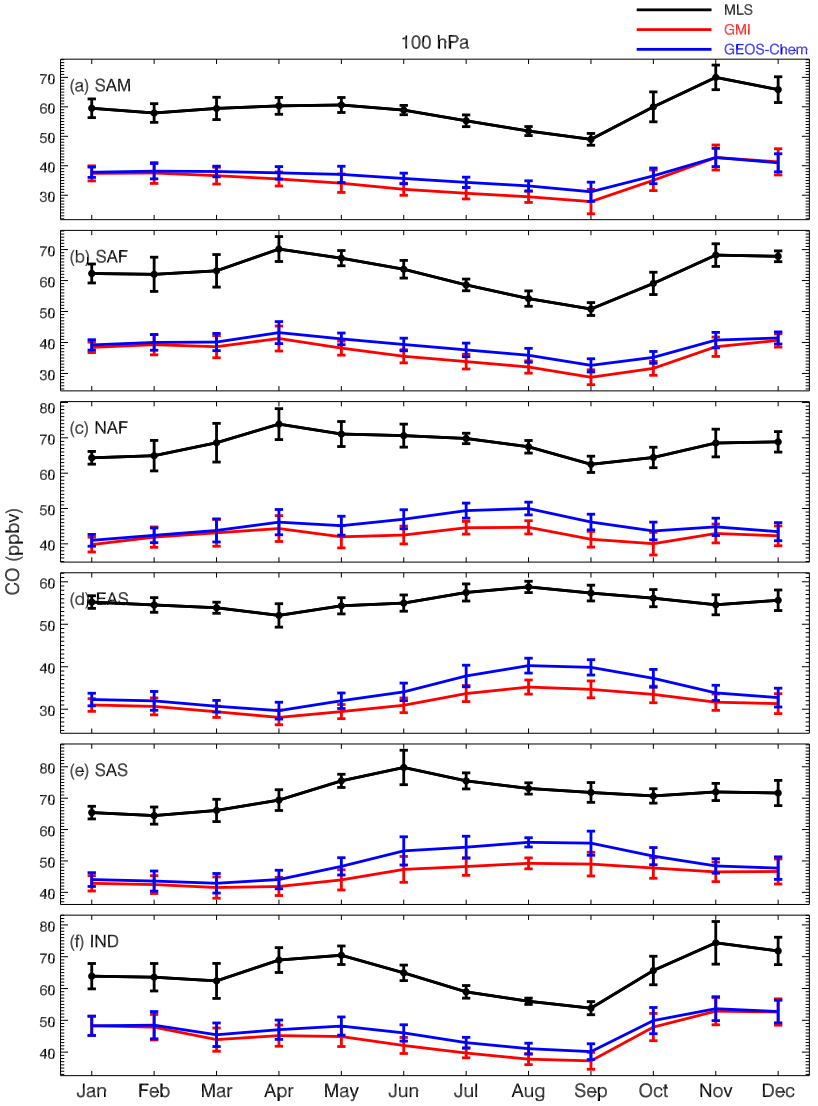

Figure 13. As in Fig. 12, but for $\mathrm{CO}$ mixing ratio at $100 \mathrm{hPa}$.

it first decreases $(215-147 \mathrm{hPa})$ and then increases (147$100 \mathrm{hPa}$ ) over East Asia. This is also shown in earlier figures for the climatological monthly mean of CO in the UTLS (Figs. 12 and 13). In general, the differences between GMI and GEOS-Chem are largest at $215 \mathrm{hPa}$ (up to $19 \%$ ) during DJF, whereas the differences reach maximum at $100 \mathrm{hPa}$ (up to $13 \%$ ) during JJA. GMI mixing ratios are greater than GEOS-Chem at altitudes below (i.e., pressures greater than) $147 \mathrm{hPa}$ over South America, Africa and Indonesia. However, it becomes slightly less than GEOS-Chem for heights above (i.e., pressures smaller than) $100 \mathrm{hPa}$. That the profile shapes are different, despite identical underlying meteorology, suggests that the way in which each CTM parameterizes its convective transport (including detrainment and entrainment) is affecting the resulting vertical distribution.

\section{Relation between emission, convection and UTLS CO}

In the sections above, we have evaluated the spatial distributions and temporal variations of CO in the UTLS simulated by the two models, on both the global and regional scale. Previous studies have shown that $\mathrm{CO}$ in the upper troposphere can be affected by both surface emission and convection (e.g., Schoeberl et al., 2006; Liu et al., 2007, 2010; 


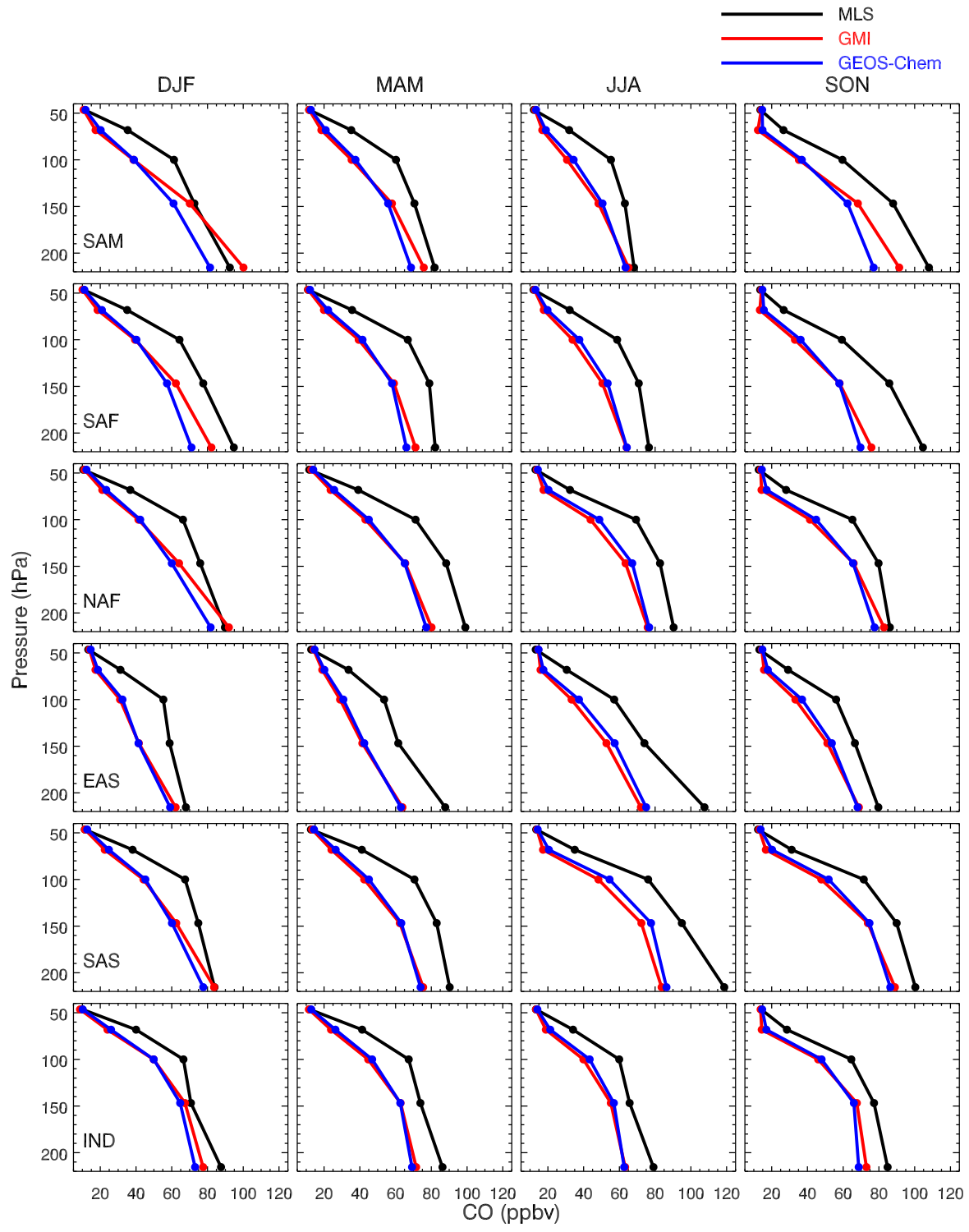

Figure 14. Climatological (8-year) seasonal mean vertical profile of CO mixing ratio from MLS V4 data (black line), GMI model simulation with MLS AKs applied (red line) and GEOS-Chem model simulation with MLS AKs applied (blue line) over the selected six regions: (top row) South America, (second row from top) southern Africa, (third row from top) northern Africa, (fourth row from top) East Asia, (fifth row from top) South Asia and (bottom row) Indonesia.

Huang et al., 2012); thus it is important to evaluate the abilities of models to simulate the relationships between surface emission, convection and CO in the UTLS. In this way, we can better understand the differences between observation and simulation of CO in the UTLS.

The climatological monthly means of surface $\mathrm{CO}$ emission from GMI (very similar to GEOS-Chem), IWC and CO at three pressure levels from MLS are shown in Fig. 15. Each variable is normalized for comparison. MLS IWC is used here as a proxy of convective intensity (CONV in Fig. 15). In general, seasonality in $\mathrm{CO}$ at $147 \mathrm{hPa}$ is similar to that at $215 \mathrm{hPa}$, but different from that at $100 \mathrm{hPa}$. The relation- ships between UTLS CO and emission and convection vary with regions. For example, over South America and southern Africa, the annual CO peak lags the emission peak by 1-2 months at 215 and $147 \mathrm{hPa}$. Over East and South Asia, the annual $\mathrm{CO}$ cycle closely follows the variation of convection at the two lower levels. Over northern Africa and Indonesia, it seems that both emission and convection are important in determining CO in the UTLS.

Due to the complexity of the emission-convection-CO relationship, we apply a bivariate composite analysis (Jiang et al., 2007), and the results are shown in Figs. 16 and 17 for $\mathrm{CO}$ at $215 \mathrm{hPa}$ over the tropics $\left(30^{\circ} \mathrm{S}-30^{\circ} \mathrm{N}\right)$ and different 


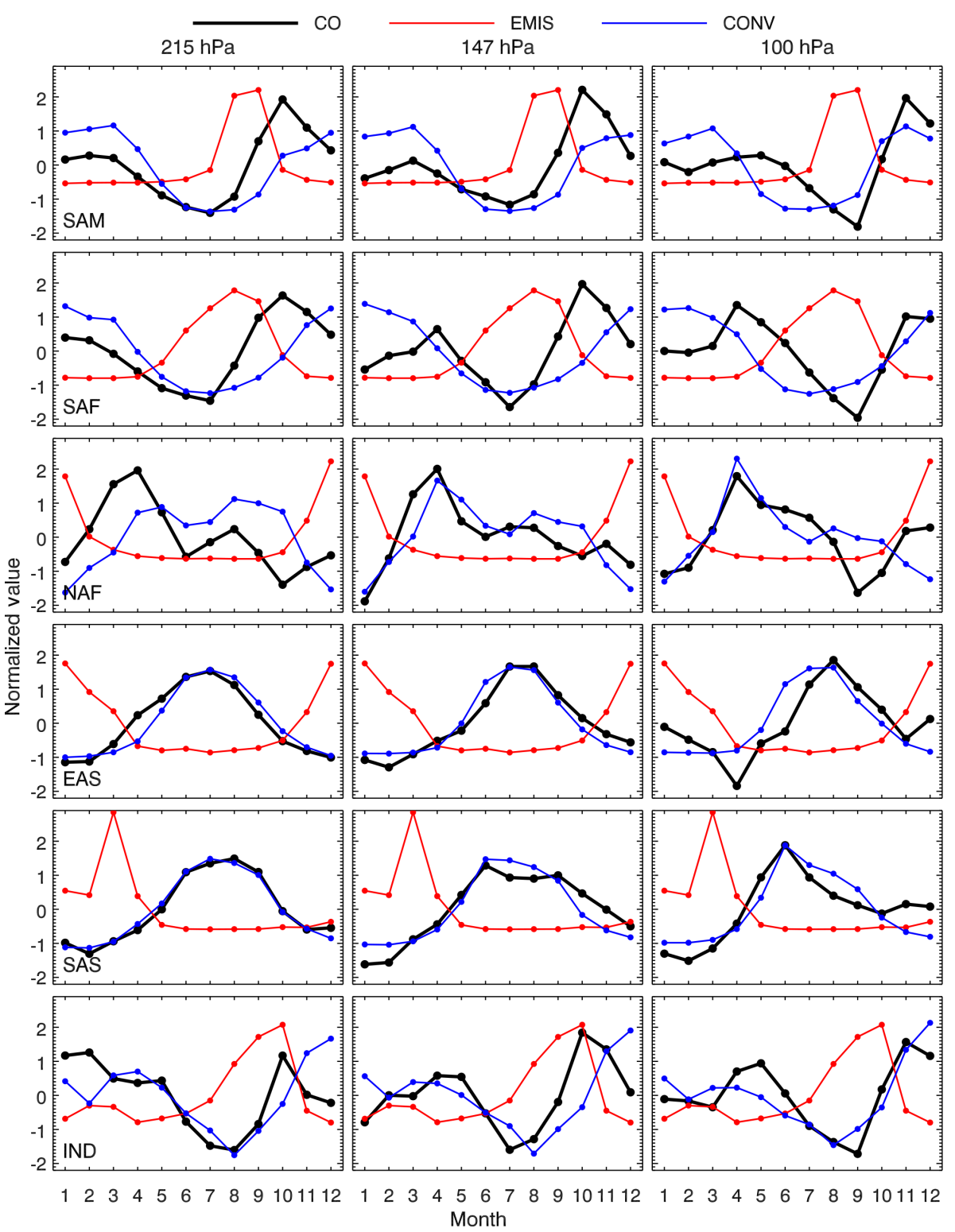

Figure 15. Climatological monthly mean of surface $\mathrm{CO}$ emission from GMI model (red line), ice water content (blue line) and CO mixing ratio (black line) at $215 \mathrm{hPa}$ (left column), $147 \mathrm{hPa}$ (middle column) and $100 \mathrm{hPa}$ (left column) from MLS observation over six regions: (top row) South America, (second row from top) southern Africa, (third row from top) northern Africa, (fourth row from top) East Asia, (fifth row from top) South Asia and (bottom row) Indonesia. Each variable is normalized for comparison.

regions, respectively. The monthly mean $\mathrm{CO}$ mixing ratios at $215 \mathrm{hPa}$ in each grid box from MLS observation and model simulations are binned according to the total (anthropogenic and biomass burning) surface $\mathrm{CO}$ emissions ( $x$ axis) and the convective (CONV) index ( $y$ axis). The CONV index is calculated as the IWC (from MLS observation) or convective mass flux (from two models' simulations) value in each grid box divided by the regional mean value at the same level. We have compared MLS IWC with convective mass flux from the models and found that they have good linear correlation (correlation coefficients $>0.7$, as shown in Fig. S12). The sur- face $\mathrm{CO}$ emission data used for GMI simulation are reused for the MLS bivariate composite analysis. The color contour indicates the unity-based normalized $\mathrm{CO}$ value (i.e., 0 is the minimum and 1 is the maximum) at each pressure level.

Over the tropics (Fig. 16), MLS shows that CO concentration at $215 \mathrm{hPa}$ is high when convection is strong. With the presence of deep convection (CONV > 1), CO generally increases with increasing surface emission. When convection is relatively weak (CONV $<0.1)$, CO is generally low and bears little connection with surface emission. $\mathrm{CO}$ concentration reaches a maximum when both convection and 


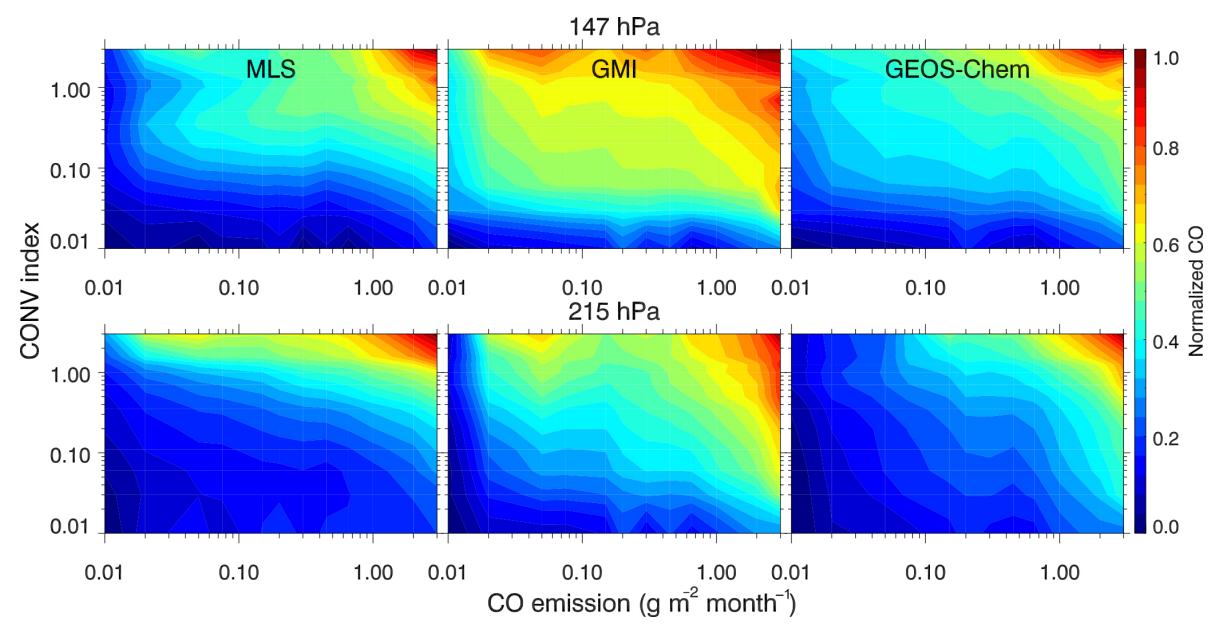

Figure 16. Contour plots of normalized $\mathrm{CO}$ mixing ratio at $215 \mathrm{hPa}$ (top row) and $147 \mathrm{hPa}$ (bottom row) over the tropics $\left(30^{\circ} \mathrm{S}-30^{\circ} \mathrm{N}\right)$ from MLS observation (left column), GMI model simulation (middle column) and GEOS-Chem model simulation (left column) binned according to the surface $\mathrm{CO}$ emission ( $x$ axis) and convective index ( $y$ axis) at the same pressure level. See text for more details.

emission are strong. When emission is very weak, the variation of CO may result from long-range transport preceding convective lofting (Huang et al., 2012). For example, MLS shows a high CO center when emission is relatively weak (between 0.02 and $0.1 \mathrm{~g} \mathrm{~m}^{-2}$ month $^{-1}$ ) and convection is strong $(\mathrm{CONV}>2)$, which is also captured in the GMI simulation, but not in the GEOS-Chem simulation. In general, both GMI and GEOS-Chem simulations show similar emission-convection-CO relationships compared with MLS observation, except the slope of $\mathrm{CO}$ contours has some differences. For instance, GMI seems to overestimate $\mathrm{CO}$ when convection is moderate $(0.05<\mathrm{CONV}<1)$ or emission is strong ( $>1 \mathrm{~g} \mathrm{~m}^{-2}$ month $^{-1}$ ), while GEOS-Chem underestimates $\mathrm{CO}$ when convection is strong $(\mathrm{CONV}>1)$ with weak emission $\left(<0.1 \mathrm{~g} \mathrm{~m}^{-2} \mathrm{month}^{-1}\right)$. At $147 \mathrm{hPa}$, the emissionconvection-CO relationships are similar to those shown at $215 \mathrm{hPa}$. For MLS observations, CO increases with emission when convection is moderate or strong $(\mathrm{CONV}>0.1)$, but the high $\mathrm{CO}$ when emission is weak with strong convection is more pronounced at 215 than $147 \mathrm{hPa}$. The emissionconvection-CO relationships simulated by GMI and GEOSChem also show similarity to MLS observation at $147 \mathrm{hPa}$, despite some differences in the slope of CO contours. At $100 \mathrm{hPa}$, the emission-convection-CO relationships simulated by the two models are quite different from MLS observation (figure not shown), probably due to the significantly underestimated convection and $\mathrm{CO}$ in the models at this level; thus we do not discuss them in detail here. For the regional discussion below, we will also only focus on 215 and $147 \mathrm{hPa}$.

Over the six different regions (Fig. 17), MLS shows that $\mathrm{CO}$ concentrations at $215 \mathrm{hPa}$ are generally high when emission and convection are strong. However, there are also distinct regional differences. Over South America, CO does not change much when convection is relatively weak $(\mathrm{CONV}<1)$, even though strong emission is present. $\mathrm{CO}$ increases rapidly when emission is large $\left(>1 \mathrm{~g} \mathrm{~m}^{-2} \mathrm{month}^{-1}\right)$ with strong convection. This suggests that local convection plays an important role in determining $\mathrm{CO}$ mixing ratio in the UT over this region, which has been demonstrated by previous studies (e.g., Huang et al., 2012). Over southern and northern Africa, two high $\mathrm{CO}$ centers occur when convection is strong $(\mathrm{CONV}>1)$; one is located in a weak emission regime $\left(0.02-0.1 \mathrm{~g} \mathrm{~m}^{-2} \mathrm{month}^{-1}\right)$ and the other is accompanied by strong emission $\left(>0.51 \mathrm{~g} \mathrm{~m}^{-2}\right.$ month $\left.^{-1}\right)$. This is similar to the two CO centers at $215 \mathrm{hPa}$ over the tropics (Fig. 16). It is noteworthy that there is a large $\mathrm{CO}$ difference between cases where emissions are $0.11 \mathrm{~g} \mathrm{~m}^{-2}$ month $^{-1}$ and those with $0.51 \mathrm{~g} \mathrm{~m}^{-2}$ month $^{-1}$ emissions over northern Africa, with the latter cases exhibiting larger CO. Over East and South Asia, CO concentration is high in all cases where deep convection is present $(\mathrm{CONV}>1)$. Even when emission is weak $\left(<0.11 \mathrm{~g} \mathrm{~m}^{-2}\right.$ month $\left.^{-1}\right)$, CO mixing ratio can still be high with strong convection, which suggests that $\mathrm{CO}$ transport by convection and advection may be important over this region. During the Asian summer monsoon season, $\mathrm{CO}$ emitted from northeast India and southwest China can be transported by deep convection to the UTLS and trapped within the anticyclonic circulation (e.g., Li et al., 2005; Fu et al., 2006; Park et al., 2009). This may account for the high $\mathrm{CO}$ over these two regions even though local emission is relatively weak. Over Indonesia, MLS roughly shows two high CO centers; one occurs when both convection and emission are strong (upper right corner) and the other exists when strong emission with weak convection is present (lower right corner).

The emission-convection-CO relationships simulated by the two models are quite similar to each other, reflecting 


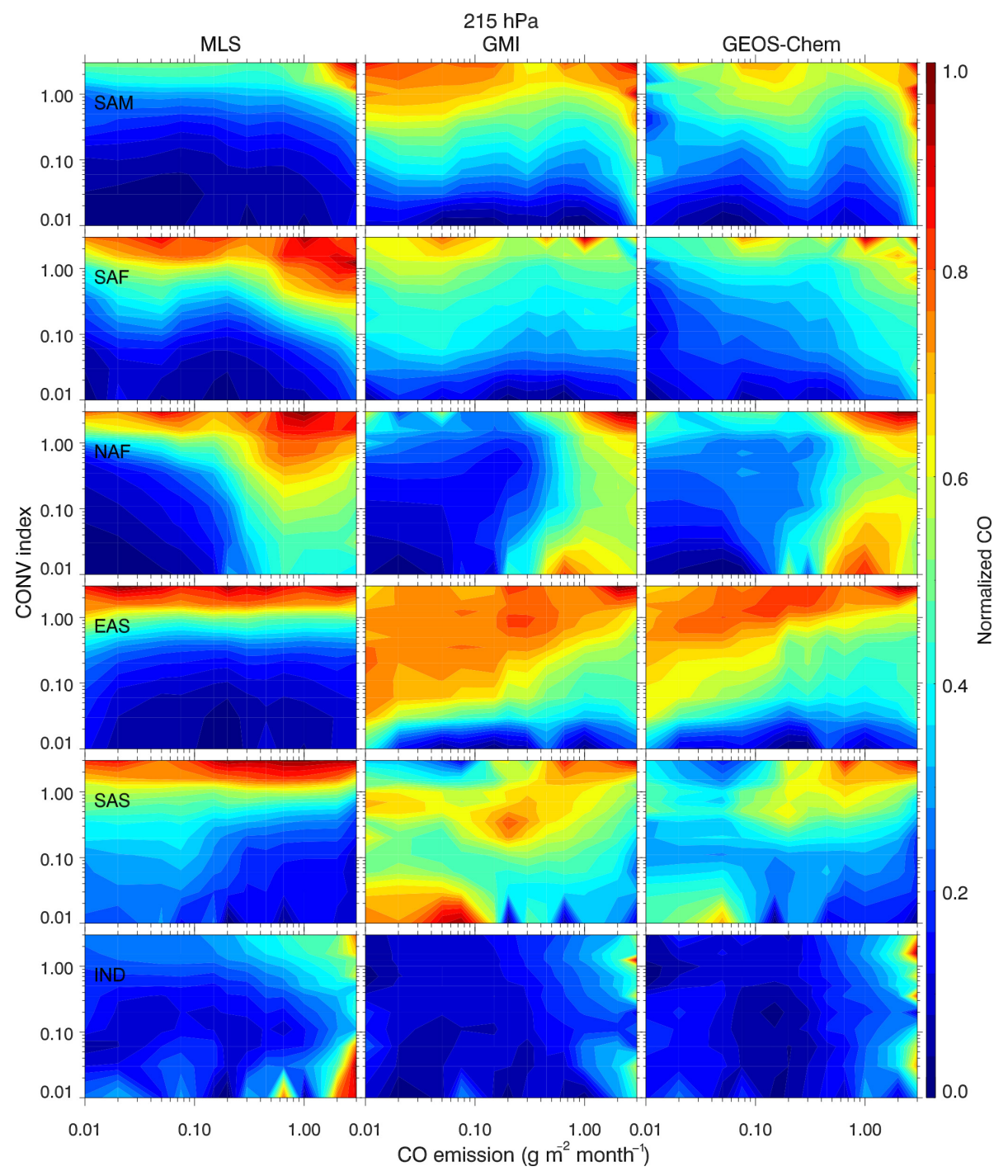

Figure 17. Contour plots of normalized CO mixing ratio at $215 \mathrm{hPa}$ over six regions: (top row) South America, (second row from top) southern Africa, (third row from top) northern Africa, (fourth row from top) East Asia, (fifth row from top) South Asia and (bottom row) Indonesia, from MLS observation (left column), GMI model simulation (middle column) and GEOS-Chem model simulation (left column) binned according to the surface $\mathrm{CO}$ emission ( $x$ axis) and convective index ( $y$ axis) at the same pressure level. See text for more details.

their underlying identical meteorology and similar emission inventories. When compared with MLS observation, there is similarity over some regions such as southern Africa, northern Africa and Indonesia. Over other regions, the observed and simulated relationships are quite different. For example, both GMI and GEOS-Chem show two CO centers when convection is strong (CONV > 1) over South America, and they overestimate $\mathrm{CO}$ when convection is moderate $(0.1<$ CONV < 1$)$. Over East Asia, both models overestimate $\mathrm{CO}$ when convection is weak or moderate, especially with weak emission $\left(<0.21 \mathrm{~g} \mathrm{~m}^{-2}\right.$ month $\left.^{-1}\right)$. Over South Asia, both models show a high $\mathrm{CO}$ center when both convection and emission are weak (lower left corner), which is not seen in the MLS observation. The emission-convection-CO rela- tionships at $147 \mathrm{hPa}$ over different regions observed by MLS, and the comparisons between observation and model simulations, are similar to those at $215 \mathrm{hPa}$; thus we will not discuss them in detail.

\section{Conclusions}

In this study, we evaluate the spatial distribution and temporal variation of $\mathrm{CO}$ in the upper troposphere and lower stratosphere (UTLS) during 2004-2012 simulated by two chemical transport models (GMI and GEOS-Chem) using the latest version (V4.2) of Aura MLS data. The seasonal and monthly variations of $\mathrm{CO}$, as well as the transport of CO in the UTLS (the tape recorder) are compared between MLS observations 
and model simulations, over both global and regional scales. In addition, the relationships between emission, convection, and $\mathrm{CO}$ mixing ratio in the UTLS are investigated over different regions using MLS observations and model simulations.

In general, the simulated $\mathrm{CO}$ distribution from GMI is quite similar to that from GEOS-Chem at all levels. However, the CO peak values of GEOS-Chem are 15-20\% smaller than GMI at 215 and $147 \mathrm{hPa}$ over South America and Africa during DJF and SON, and 20\% larger than GMI at $100 \mathrm{hPa}$ over South Asia during JJA. Compared with MLS observation, the locations of high $\mathrm{CO}$ centers at 215 and $147 \mathrm{hPa}$ are well simulated in GMI and GEOS-Chem, except over Africa. The UTLS transport of CO from East Asia across the Pacific to North America in MAM and JJA is shown in the two models' simulations, but the $\mathrm{CO}$ concentrations are much lower than those observed by MLS. In addition, the magnitudes of simulated CO peaks are much smaller than MLS observation, with a maximum underestimation of $\sim 40 \%$ at $215 \mathrm{hPa}$, $50-60 \%$ at $147 \mathrm{hPa}$ and $\sim 70 \%$ at $100 \mathrm{hPa}$. For the vertical distribution of zonally averaged $\mathrm{CO}$, the model simulations show more diffuse UT horizontal gradients, stronger vertical gradients below $100 \mathrm{hPa}$ and weaker gradients above $100 \mathrm{hPa}$ than observed by MLS, which may be due to the underestimated upward transport of $\mathrm{CO}$. The two models successfully reproduce the seasonal shift of $\mathrm{CO}$ centers in the UT from DJF to JJA, but they fail to simulate a higher CO maximum in the southern subtropics during SON.

The high $\mathrm{CO}$ concentrations in the northern subtropics are largely underestimated in the models from April to July, especially over South Asia and East Asia. By contrast, the temporal variation of $\mathrm{CO}$ in the southern subtropics is well simulated by the models, except that the magnitude is slightly smaller than observed. The high $\mathrm{CO}$ values in the UT related to stronger $\mathrm{CO}$ emissions generated by drought-induced fires in Indonesia or South America are well captured by GMI during ENSO periods. The semi-annual CO peaks at $100 \mathrm{hPa}$ are not well simulated by the two models, and the peak during MAM is much weaker than the other peak during SON. In general, the observed and simulated CO tape recorders show good agreement over the tropics and southern subtropics. The phase shift and CO anomaly magnitude in the GMI simulation are more consistent with MLS observation than those in the GEOS-Chem simulation. The models show that the location of the tape head is near $200 \mathrm{hPa}$, which is in rough agreement with MLS data. Over the northern subtropics, CO tape recorders simulated by the models show a $2-3$ month time lag between the same phases of $\mathrm{CO}$ peak anomaly, which may be caused by an underestimation of vertical transport in the models.

On regional scales, the $\mathrm{CO}$ concentrations simulated by GMI are generally larger than those from GEOS-Chem, with differences less than $10 \%$ at 215 and $147 \mathrm{hPa}$. The seasonal cycle of CO is similar between MLS and both models over South America, southern Africa and Indonesia, although the magnitude greatly differs. Over three other regions (northern
Africa, East Asia and South Asia), the simulated seasonal variation of $\mathrm{CO}$ is not consistent with MLS observation. At $100 \mathrm{hPa}$, GMI is smaller than GEOS-Chem over all regions, especially from May to October. The underestimation of $\mathrm{CO}$ by the models reaches its maximum at this level. Vertical CO profile comparisons show that the models underestimate $\mathrm{CO}$ at all levels below (i.e., with pressures greater than) $50 \mathrm{hPa}$ observable by MLS, with the magnitude of underestimation depending on region, altitude and season.

The relationships between emission, convection and UTLS CO vary with region. Over the tropics, UT CO generally increases with increasing surface emission in the presence of deep convection. When convection is relatively weak, UT CO is generally low and changes little with surface emission. The maximum $\mathrm{CO}$ concentration occurs when both convection and emission are strong. GMI and GEOS-Chem simulations generally show similar emission-convectionCO relationships compared with MLS observation at 215 and $147 \mathrm{hPa}$, except the slope of $\mathrm{CO}$ contours have some differences. At $100 \mathrm{hPa}$, the emission-convection-CO relationships simulated by the two models are quite different from observations. On a regional scale, $\mathrm{CO}$ in the UT is generally high when emission and convection are strong, but distinct regional differences also exist, which may be associated with the relative importance of convection and advection in $\mathrm{CO}$ transport over different regions. In addition, convection in the tropics and midlatitudes is fundamentally different, leading to differences in $\mathrm{CO}$ transport, and the relative mix of $\mathrm{CO}$ from anthropogenic emission, biomass burning and in situ production. The simulated emission-convection-CO relationships from GMI and GEOS-Chem are similar to observation over some regions such as southern Africa, northern Africa and Indonesia, but not all regions.

Overall, GMI and GEOS-Chem simulations of $\mathrm{CO}$ are similar given the same driving meteorology and very similar emission inventories. However, model simulations still show large discrepancies compared with MLS observations, especially in the lower stratosphere, such as at $100 \mathrm{hPa}$. These discrepancies may be related to the convection parameterization, inaccurate emission inventories and chemical production and loss rate of $\mathrm{CO}$ in the troposphere (e.g., Table 2). More efforts are needed to investigate these factors to improve model simulations in future studies. 
Appendix A: Comparison of MLS version 3 and version $4 \mathrm{CO}$

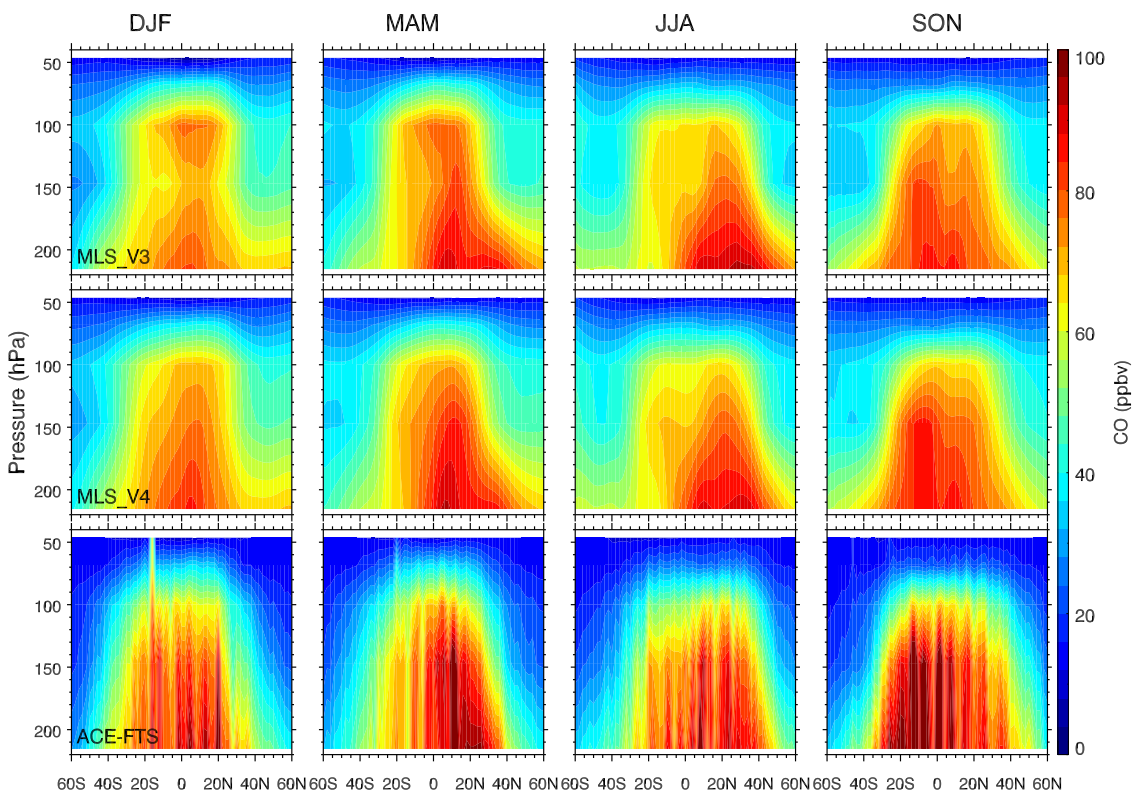

Figure A1. Vertical distribution of zonal mean CO mixing ratio in the pressure-latitude cross section during different seasons (DJF, MAM, JJA and SON) from (top row) MLS Version 3 CO data; (middle row) MLS Version 4 CO data; (bottom row) ACE-FTS CO data with MLS averaging kernels (AKs) applied.

Our preliminary comparisons of MLS V3 and V4 CO data have shown that the spatial distributions of $\mathrm{CO}$ in the UTLS are quite similar, except for some small differences in the magnitude. In general, $\mathrm{CO}$ concentration differences between these two versions are within $20 \%$. The seasonal $\mathrm{CO}$ peak values of V4 are slightly larger than V3 at 215 and $147 \mathrm{hPa}$, but become smaller than $\mathrm{V} 3$ at $100 \mathrm{hPa}$. The maximum differences is $\sim 12-17 \%$ for different seasons.

The improvements of MLS V4 compared with V3 CO can be seen in the vertical distribution of zonal mean $\mathrm{CO}$ (Fig. A1) and the vertical CO profiles (Fig. A2). One improvement is that the cloud contamination is significantly reduced; the other is the more realistic $\mathrm{CO}$ gradient from 215 to $100 \mathrm{hPa}$. In order to better illustrate the differences between different versions, we also add the $\mathrm{CO}$ measurements from the Atmospheric Chemistry Experiment - Fourier Transform Spectrometer (ACE-FTS) (Bernath et al., 2005). This instrument is on-board the Canadian satellite SCISAT-1, operating between 750 and $4400 \mathrm{~cm}^{-1}$ with a high spectralresolution $\left(0.02 \mathrm{~cm}^{-1}\right)$ and using a solar occultation observation technique. ACE-FTS observations are used to derive volume mixing ratio profiles of over 30 atmospheric trace gases (Boone et al., 2005), measuring each spacecraft sunrise and sunset $(\sim 30$ profiles per day compared to $\sim 3500$ for Aura MLS). It has been providing consistent measurements since February 2004. The atmospheric profiles provided by ACE-FTS range in altitude of $\sim 5-110 \mathrm{~km}$ depending on the species, with a vertical resolution of $\sim 3-4 \mathrm{~km}$. The data used are ACE-FTS Level 2 Version 3.5 (V3.5) (Boone et al., 2013) with the same period as MLS data (August 2004-December 2012).

The vertical distribution of zonal mean $\mathrm{CO}$ in the pressure-latitude cross section and its seasonal variations as observed by MLS and ACE-FTS are shown in Fig. A1. During boreal winter (DJF), MLS V3 CO shows a decrease between 160 and $130 \mathrm{hPa}$, which may be caused by cloud contamination. This abnormal gap does not exist in MLS V4 and ACE-FTS CO observation. Such improvement is also shown during MAM. In addition, the magnitude of high $\mathrm{CO}$ centers in MLS V4 is higher than that in MLS V3 and has better agreement with ACE-FTS measurement. The tropical average $\left(30^{\circ} \mathrm{S}-30^{\circ} \mathrm{N}\right)$ of $\mathrm{CO}$ vertical profile in the UTLS and its seasonal variation as observed by MLS and ACE-FTS are shown in Fig. A2. Compared with MLS V3 data, V4 $\mathrm{CO}$ is slightly more realistic in the $\mathrm{CO}$ gradient from 215 to $100 \mathrm{hPa}$. For example, MLS V3 data show that CO decreases from 215 to $147 \mathrm{hPa}$ and then increases from 147 to $100 \mathrm{hPa}$ during DJF season, but V4 data show that it monotonically decreases from 215 to $100 \mathrm{hPa}$, which is consistent with ACE-FTS CO observation. This improvement is also found in regional analysis (e.g., Indonesia). Furthermore, MLS V4 CO also shows better agreement with ACE-FTS $\mathrm{CO}$ than $\mathrm{V} 3 \mathrm{CO}$ during other seasons. 


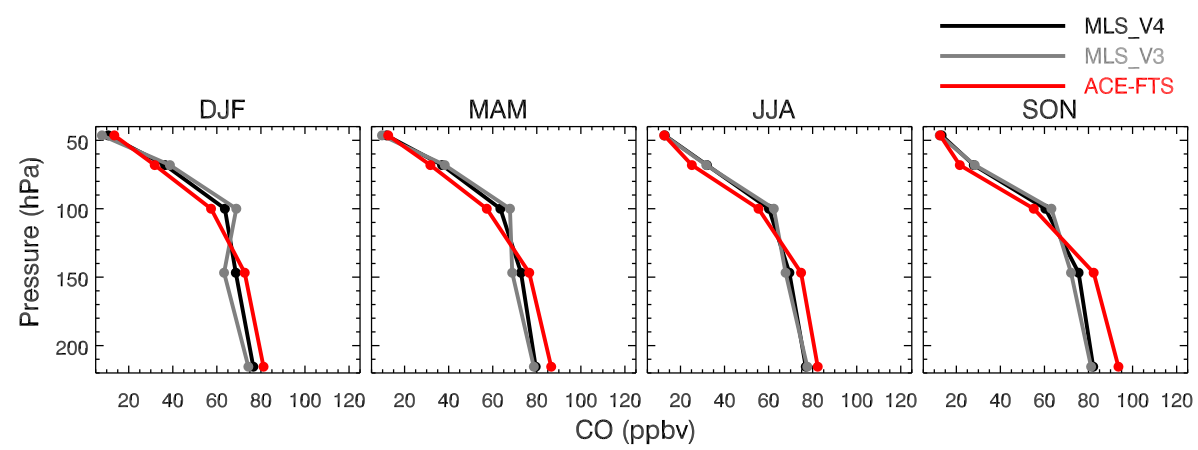

Figure A2. Climatological (8-year) seasonal mean vertical profile of CO mixing ratio from MLS Version 4 CO data (black line), MLS Version $3 \mathrm{CO}$ data (gray line) and ACE-FTS CO data with MLS AKs applied (red line) over the tropics $\left(30^{\circ} \mathrm{S}-30^{\circ} \mathrm{N}\right)$. 
Acknowledgements. This research is supported by the NASA Aura Science Team program. The study was performed at the Jet Propulsion Laboratory (JPL), California Institute of Technology, under contract with NASA. The first author would like to thank William G. Read for help with the application of MLS averaging kernels to model simulations, and Susan E. Strahan and Stephen D. Steenrod for helpful advice on GMI model data analysis. We appreciate the helpful comments from two anonymous reviewers that led to significant improvements of this paper.

Edited by: B. N. Duncan

\section{References}

Alexander, B., Savarino, J., Lee, C. C. W., Park, R. J., Jacob, D. J., Thiemens, M. H., Li, Q. B., and Yantosca, R. M.: Sulfate formation in sea-salt aerosols: Constraints from oxygen isotopes, J. Geophys. Res., 110, D10307, doi:10.1029/2004JD005659, 2005.

Allen, D. J., Kasibhatla, P., Thompson, A. M., Rood, R. B., Doddridge, B. G., Pickering, K. E., Hudson, R. D., and Lin, S.: Transport-induced interannual variability of carbon monoxide determined using a chemistry and transport model, J. Geophys. Res., 101, 28655-28669, 1996.

Barkley, M., Palmer, P., Ganzeveld, L., Arneth, A., Hagberg, D., Karl, T., Guenther, A., Paulot, F., Wennberg, P., Mao, J., Kurosu, T., Chance, K., Muller, J.-F., De Smedt, I., Van Roozendael, M., Chen, D., Wang, Y., and Yantosca, R.: Can a "state of the art" chemistry transport model simulate Amazonian tropospheric chemistry?, J. Geophys. Res., 116, D16302, doi:10.1029/2011JD015893, 2011.

Bernath, P. F., McElroy, C. T., Abrams, M. C., Boone, C. D., Butler, M., Camy-Peyret, C., Carleer, M., Clerbaux, C., Coheur, P.-F., Colin, R., DeCola, P., DeMazière, M., Drummond, J. R., Dufour, D., Evans, W. F. J., Fast, H., Fussen, D., Gilbert, K., Jennings, D. E., Llewellyn, E. J., Lowe, R. P., Mahieu, E., McConnell, J. C., McHugh, M., McLeod, S. D., Michaud, R., Midwinter, C., Nassar, R., Nichitiu, F., Nowlan, C., Rinsland, C. P., Rochon, Y. J., Rowlands, N., Semeniuk, K., Simon, P., Skelton, R., Sloan, J. J., Soucy, M.-A., Strong, K., Tremblay, P., Turnbull, D., Walker, K. A.,Walkty, I., Wardle, D. A., Wehrle, V., Zander, R., and Zou, J.: Atmospheric Chemistry Experiment (ACE): Mission overview, Geophys. Res. Lett., 32, L15S01, doi:10.1029/2005GL022386, 2005.

Bey, I., Aumont, B., and Toupance, G.: A modeling study of the nighttime radical chemistry in the lower continental troposphere: 1. Development of a detailed chemical mechanism including nighttime chemistry, J. Geophys. Res., 106, 9959-9990, doi:10.1029/2000JD900347, 2001a.

Bey, I., Jacob, D. J., Yantosca, R. M., Logan, J. A., Field, B. D., Fiore, A. M., Li, Q. B., Liu, H. G. Y., Mickley, L. J., and Schultz, M. G.: Global modeling of tropospheric chemistry with assimilated meteorology: Model description and evaluation, J. Geophys. Res., 106, 23073-23096, 2001 b.

Bian, H. and Prather, M. J.: Fast-J2: Accurate Simulation of stratospheric photolysis in global chemical models, J. Atmos. Chem., 41, 281-296, 2002.

Boone, C. D., Nassar, R., Walker, K. A., Rochon, Y., McLeod, S. D., Rinsland, C. P., and Bernath, P. F.: Retrievals for the Atmo- spheric Chemistry Experiment Fourier-Transform Spectrometer, Appl. Optics, 44, 7218-7231, doi:10.1364/AO.44.007218, 2005.

Boone, C. D., Walker, K. A., and Bernath, P. F.: Version 3 Retrievals for the Atmospheric Chemistry Experiment Fourier Transform Spectrometer (ACE-FTS), The Atmospheric Chemistry Experiment ACE at 10: A Solar Occultation Anthology, A. Deepak Publishing, Hampton, Virginia, USA, 103-127, 2013.

Brewer, A. W.: Evidence for a World Circulation Provided by the Measurements of Helium and Water Vapour Distribution in the Stratosphere, Q. J. Roy. Meteor. Soc., 75, 351-363, 1949.

Daniel, J. S. and Solomon, S.: On the climate forcing of carbon monoxide, J. Geophys. Res., 103, 13249-13260, 1998.

De Laat, A., Gloudemans, A., Aben, I., Krol, M., Meirink, J., van der Werf, G., and Schrijver, H.: SCIAMACHY carbon monoxide total columns: statistical evaluation and comparison with CTM results, J. Geophys. Res., 112, D12310, doi:10.1029/2006JD008256, 2007.

Duncan, B. N., Strahan, S. E., Yoshida, Y., Steenrod, S. D., and Livesey, N.: Model study of the cross-tropopause transport of biomass burning pollution, Atmos. Chem. Phys., 7, 3713-3736, doi:10.5194/acp-7-3713-2007, 2007.

Edwards, D. P., Emmons, L. K., Gille, J. C., Chu, A., Attie, J. L., Giglio, L., Wood, S. W., Haywood, J., Deeter, M. N., Massie, S. T., Ziskin, D. C., and Drummond, J. R.: Satellite-observed pollution from Southern Hemisphere biomass burning, J. Geophys Res., 111, D14312, doi:10.1029/2005JD006655, 2006.

Fisher, J. A., Wilson, S. R., Zeng, G., Williams, J. E., Emmons, L. K., Langenfelds, R. L., Krummel, P. B., and Steele, L. P.: Seasonal changes in the tropospheric carbon monoxide profile over the remote Southern Hemisphere evaluated using multi-model simulations and aircraft observations, Atmos. Chem. Phys., 15, 3217-3239, doi:10.5194/acp-15-3217-2015, 2015.

Fu, R., Hu, Y. L., Wright, J. S., Jiang, J. H., Dickinson, R. E., Chen, M. X., Filipiak, M., Read, W. G., Waters, J. W., and $\mathrm{Wu}, \mathrm{D}$. L.: Short circuit of water vapor and polluted air to the global stratosphere by convective transport over the Tibetan Plateau, P. Natl. Acad. Sci. USA, 103, 5664-5669, doi:10.1073/pnas.0601584103, 2006.

Gloudemans, A., Krol, M., Meirink, J., De Laat, A., Van der Werf, G., Schrijver, H., Van den Broek, M., and Aben, I.: Evidence for long-range transport of carbon monoxide in the Southern Hemisphere from SCIAMACHY observations, Geophys. Res. Lett., 33, L16807, doi:10.1029/2006GL026804, 2006.

Gonzi, S. and Palmer, P. I.: Vertical transport of surface fire emissions observed from space, J. Geophys. Res., 115, D02306, doi:10.1029/2009JD012053, 2010.

Guenther, A., Karl, T., Harley, P., Wiedinmyer, C., Palmer, P. I., and Geron, C.: Estimates of global terrestrial isoprene emissions using MEGAN (Model of Emissions of Gases and Aerosols from Nature), Atmos. Chem. Phys., 6, 3181-3210, doi:10.5194/acp-63181-2006, 2006.

Heald, C. L., Jacob, D. J., Jones, D. B. A., Palmer, P. I., Logan, J. A., Streets, D. G., Sachse, G. W., Gille, J. C., Hoffman, R. N., andNehrkorn, T.: Comparative inverse analysis of satellite (MOPITT) and aircraft (TRACE-P) observations to estimate Asian sources of carbon monoxide, J. Geophys. Res., 109, D23306, doi:10.1029/2004JD005185, 2004.

Huang, L., Fu, R., Jiang, J. H., Wright, J. S., and Luo, M.: Geographic and seasonal distributions of $\mathrm{CO}$ transport pathways and 
their roles in determining $\mathrm{CO}$ centers in the upper troposphere, Atmos. Chem. Phys., 12, 4683-4698, doi:10.5194/acp-12-46832012, 2012.

Huang, L., Fu, R., and Jiang, J. H.: Impacts of fire emissions and transport pathways on the interannual variation of $\mathrm{CO}$ in the tropical upper troposphere, Atmos. Chem. Phys., 14, 4087-4099, doi:10.5194/acp-14-4087-2014, 2014.

Hudman, R. C., Jacob, D. J., Turquety, S., Leibensperger, E. M., Murray, L. T., Wu, S., Gilliland, A. B., Avery, M., Bertram, T. H., Brune, W., Cohen, R. C., Dibb, J. E., Flocke, F. M., Fried, A., Holloway, J., Neuman, J. A., Orville, R., Perring, A., Ren, X., Sachse, G. W., Singh, H. B., Swanson, A., and Wooldridge, P. J.: Surface and lightning sources of nitrogen oxides over the United States: Magnitudes, chemical evolution, and outflow, J. Geophys. Res., 112, D12S05, doi:10.1029/2006JD007912, 2007

Jacob, D. J.: Introduction to Atmospheric Chemistry, Princeton University Press, Princeton, New Jersey, USA, 1999.

Jiang, J. H., Livesey, N. J., Su, H., Neary, L., McConnell, J. C., and Richards, N. A. D.: Connecting surface emissions, convective uplifting, and long-range transport of carbon monoxide in the upper troposphere: New observations from the Aura Microwave Limb Sounder, Geophys. Res. Lett., 34, L18812, doi:10.1029/2007g1030638, 2007.

Jiang, J. H., Su, H., Zhai, C., Massie, S. T., Schoeberl, M. R., Colarco, P. R., Platnick, S., Gu, Y., and Liou, K.-N.: Influence of convection and aerosol pollution on ice cloud particle effective radius, Atmos. Chem. Phys., 11, 457-463, doi:10.5194/acp-11457-2011, 2011.

Kiehl, J. T., Hack, J. J., Bonan, G. B., Boville, B. A., Williamson, D. L., and Rasch, P. J.: The National Center for Atmospheric Research Community Climate Model: CCM3, J. Clim., 11, 11311149, 1998.

Kopacz, M., Jacob, D. J., Henze, D., Heald, C. L., Streets, D. G., and Zhang, Q.: Comparison of adjoint and analytical Bayesian inversion methods for constraining Asian sources of carbon monoxide using satellite (MOPITT) measurements of CO columns, J. Geophys. Res., 114, D04305, doi:10.1029/2007JD009264, 2009.

Kopacz, M., Jacob, D. J., Fisher, J. A., Logan, J. A., Zhang, L., Megretskaia, I. A., Yantosca, R. M., Singh, K., Henze, D. K., Burrows, J. P., Buchwitz, M., Khlystova, I., McMillan, W. W., Gille, J. C., Edwards, D. P., Eldering, A., Thouret, V., and Nedelec, P.: Global estimates of $\mathrm{CO}$ sources with high resolution by adjoint inversion of multiple satellite datasets (MOPITT, AIRS, SCIAMACHY, TES), Atmos. Chem. Phys., 10, 855-876, doi:10.5194/acp-10-855-2010, 2010.

Li, Q. B., Jiang, J. H., Wu, D. L., Read, W. G., Livesey, N. J., Waters, J. W., Zhang, Y. S., Wang, B., Filipiak, M. J., Davis, C. P., Turquety, S., Wu, S. L., Park, R. J., Yantosca, R. M., and Jacob, D. J.: Convective outflow of South Asian pollution: A global CTM simulation compared with EOS MLS observations, Geophys. Res. Lett., 32, L14826, doi:10.1029/2005GL022762, 2005.

Liu, C. T., Zipser, E., Garrett, T., Jiang, J. H., and Su, H.: How do the water vapor and carbon monoxide "tape recorders" start near the tropical tropopause?, Geophys. Res. Lett., 34, L09804, doi:10.1029/2006g1029234, 2007.

Liu, J., Logan, J. A., Jones, D. B. A., Livesey, N. J., Megretskaia, I., Carouge, C., and Nedelec, P.: Analysis of CO in the tropical troposphere using Aura satellite data and the GEOS-Chem model: insights into transport characteristics of the GEOS me- teorological products, Atmos. Chem. Phys., 10, 12207-12232, doi:10.5194/acp-10-12207-2010, 2010.

Liu, J., Logan, J. A., Murray, L. T., Pumphrey, H. C., Schwartz, M. J., and Megretskaia, I. A.: Transport analysis and source attribution of seasonal and interannual variability of $\mathrm{CO}$ in the tropical upper troposphere and lower stratosphere, Atmos. Chem. Phys., 13, 129-146, doi:10.5194/acp-13-129-2013, 2013.

Livesey, N. J., Filipiak, M. J., Froidevaux, L., Read, W. G., Lambert, A., Santee, M. L., Jiang, J. H., Pumphrey, H. C., Waters, J. W., Cofield, R. E., Cuddy, D. T., Daffer, W. H., Drouin, B. J., Fuller, R. A., Jarnot, R. F., Jiang, Y. B., Knosp, B. W., Li, Q. B., Perun, V. S., Schwartz, M. J., Snyder, W. V., Stek, P. C., Thurstans, R. P., Wagner, P. A., Avery, M., Browell, E. V., Cammas, J. P., Christensen, L. E., Diskin, G. S., Gao, R. S., Jost, H. J., Loewenstein, M., Lopez, J. D., Nedelec, P., Osterman, G. B., Sachse, G. W., and Webster, C. R.: Validation of Aura Microwave Limb Sounder O-3 and CO observations in the upper troposphere and lower stratosphere, J. Geophys. Res.-Atmos., 113, D15S02, doi:10.1029/2007jd008805, 2008.

Livesey, N. J., Read, W. G., Froidevaux, L., Lambert, A., and Manney, G. L.: EOS MLS version 3.3 Level 2 data quality and description document, Jet Propulsion Laboratory, California Institute of Technology, Pasadena, CA, 2011.

Livesey, N. J., Logan, J. A., Santee, M. L., Waters, J. W., Doherty, R. M., Read, W. G., Froidevaux, L., and Jiang, J. H.: Interrelated variations of $\mathrm{O}_{3}, \mathrm{CO}$ and deep convection in the tropical/subtropical upper troposphere observed by the Aura Microwave Limb Sounder (MLS) during 2004-2011, Atmos. Chem. Phys., 13, 579-598, doi:10.5194/acp-13-579-2013, 2013.

Livesey, N. J., Read, W. G., Wagner, P. A., Froidevaux, L., Lambert, A., Manney, G. L., Millán, L., Pumphrey, H. C., Santee, M. L., Schwartz, M. J., Wang, S., Fuller, R. A., Jarnot, R. F., Knosp, B. W., and Martinez, E.: EOS MLS Version 4.2x Level 2 data quality and description document, Jet Propulsion Laboratory, California Institute of Technology, Pasadena, CA, 2015.

Logan, J. A., Prather, M. J., Wofsy, S. C., and McElroy, M. B.: Tropospheric chemistry: A global perspective, J. Geophys. Res., 86, 7210-7254, 1981.

Mote, P. W., Rosenlof, K. H., Holton, J. R., Harwood, R. S., and Waters, J. W.: Seasonal variations of water vapor in the tropical lower stratosphere, Geophys. Res. Lett., 22, 1093-1096, 1995.

Murray, L. T., Logan, J. A., and Jacob, D. J.: Interannual variability in tropical tropospheric ozone and $\mathrm{OH}$ : the role of lightning, J. Geophys. Res., 118, 11468-11480, doi:10.1002/jgrd.50857, 2013.

Naik, V., Voulgarakis, A., Fiore, A. M., Horowitz, L. W., Lamarque, J.-F., Lin, M., Prather, M. J., Young, P. J., Bergmann, D., Cameron-Smith, P. J., Cionni, I., Collins, W. J., Dalsøren, S. B., Doherty, R., Eyring, V., Faluvegi, G., Folberth, G. A., Josse, B., Lee, Y. H., MacKenzie, I. A., Nagashima, T., van Noije, T. P. C., Plummer, D. A., Righi, M., Rumbold, S. T., Skeie, R., Shindell, D. T., Stevenson, D. S., Strode, S., Sudo, K., Szopa, S., and Zeng, G.: Preindustrial to present-day changes in tropospheric hydroxyl radical and methane lifetime from the Atmospheric Chemistry and Climate Model Intercomparison Project (ACCMIP), Atmos. Chem. Phys., 13, 5277-5298, doi:10.5194/acp-13-5277-2013, 2013.

Park, M., Randel, W. J., Emmons, L. K., and Livesey, N. J.: Transport pathways of carbon monoxide in the Asian sum- 
mer monsoon diagnosed from Model of Ozone and Related Tracers (MOZART), J. Geophys. Res., 114, D08303, doi:10.1029/2008JD010621, 2009.

Park, R. J., Jacob, D. J., Chin, M., and Martin, R. V.: Sources of carbonaceous aerosols over the United States and implications for natural visibility, J. Geophys. Res., 108, 4355, doi:10.1029/2002JD003190, 2003.

Randel, W. J. and Jensen, E. J.: Physical processes in the tropical tropopause layer and their roles in a changing climate, Nat. Geosci., 6, 169-176, doi:10.1038/ngeo1733, 2013.

Randel, W. J., Park, M., Emmons, L., Kinnison, D., Bernath, P., Walker, K. A., Boone, C., and Pumphrey, H.: Asian monsoon transport of pollution to the stratosphere, Science, 328, 611-613, 2010.

Ricaud, P., Barret, B., Attié, J.-L., Motte, E., Le Flochmoën, E., Teyssèdre, H., Peuch, V.-H., Livesey, N., Lambert, A., and Pommereau, J.-P.: Impact of land convection on tropospherestratosphere exchange in the tropics, Atmos. Chem. Phys., 7, 5639-5657, doi:10.5194/acp-7-5639-2007, 2007.

Rienecker, M. M., Suarez, M. J., Gelaro, R., Todling, R., Bacmeister, J., Liu, E., Bosilovich, M. G., Schubert, S. D., Takacs, L., Kim, G.-K., Bloom, S., Chen, J., Collins, D., Conaty, A., da Silva, A., Gu, W., Joiner, J., Koster, R. D., Lucchesi, R., Molod, A., Owens, T., Pawson, S., Pegion, P., Redder, C. R., Reichle, R., Robertson, F. R., Ruddick, A. G., Sienkiewicz, M., and Woollen, J.: MERRA: NASA's Modern-Era Retrospective Analysis for Research and Applications, J. Climate, 24, 3624-3648, doi:10.1175/JCLI-D-11-00015.1, 2011.

Rotman, D. A., Tannahill J. R., Kinnison D. E., Connell, P. S., Bergmann, D., Proctor, D., Rodriguez, J. M., Lin, S. J., Rood, R. B., Prather, M. J., Rasch, P. J., Considine, D. B., Ramaroson, R., and Kawa, S. R.: Global Modeling Initiative assessment model: Model description, integration, and testing of the transport shell, J. Geophys. Res., 106, 1669-1691, doi:10.1029/2000JD900463, 2001.

Schoeberl, M. R., Duncan, B. N., Douglass, A. R., Waters, J., Livesey, N., Read, W., and Filipiak, M.: The carbon monoxide tape recorder, Geophys. Res. Lett., 33, L12811, doi:10.1029/2006g1026178, 2006.

Schultz, M., Rast, S., van het Bolscher, M., Pulles, T., Brand, R., Pereira, J., Mota, B., Spessa, A., Dalsøren, S., van Nojie, T., and Szopa, S.: Emission data sets and methodologies for estimating emissions, RETRO project report D1-6, Hamburg, 2007.

Shindell, D., Faluvegi, G., Stevenson, D., Krol, M., Emmons, L., Lamarque, J.-F., Petron, G., Dentener, F., Ellingsen, K., Schultz, M., Wild, O., Amann, M., Atherton, C. S., Bergmann, D. J., Bey, I., Butler, T., Cofala, J., Collins, W. J., Derwent, R. G., Doherty, R. M.,Drevet, J., Eskes, H. J., Fiore, A. M., Gauss, M., Hauglustaine, D. A., Horowitz, L. W., Isaksen, I. S. A., Lawrence, M. G., Montanaro, V., Müller, J.-F., Pitari, G., Prather, M. J., Pyle, J. A., Rast, S., Rodriguez, J. M., Sanderson, M. G., Savage, N. H., Strahan, S. E., Sudo, K., Szopa, S., Unger, N., van Noije, T. P. C., and Zeng, G.: Multimodel simulations of carbon monoxide: Comparison with observations and projected near-future changes, J. Geophys. Res., 111, D19306, doi:10.1029/2006JD007100, 2006.

van der Werf, G. R., Randerson, J. T., Giglio, L., Collatz, G. J., Mu, M., Kasibhatla, P. S., Morton, D. C., DeFries, R. S., Jin, Y., and van Leeuwen, T. T.: Global fire emissions and the contribution of deforestation, savanna, forest, agricultural, and peat fires (1997-
2009), Atmos. Chem. Phys., 10, 11707-11735, doi:10.5194/acp10-11707-2010, 2010.

van Donkelaar, A., Martin, R. V., Leaitch, W. R., Macdonald, A. M., Walker, T. W., Streets, D. G., Zhang, Q., Dunlea, E. J., Jimenez, J. L., Dibb, J. E., Huey, L. G., Weber, R., and Andreae, M. O.: Analysis of aircraft and satellite measurements from the Intercontinental Chemical Transport Experiment (INTEX-B) to quantify long-range transport of East Asian sulfur to Canada, Atmos. Chem. Phys., 8, 2999-3014, doi:10.5194/acp-8-2999-2008, 2008.

Waters, J. W., Froidevaux, L., Harwood, R. S., Jarnot, R. F., Pickett, H. M., Read, W. G., Siegel, P. H., Cofield, R. E., Filipiak, M. J., Flower, D. A., Holden, J. R., Lau, G. K., Livesey, N. J., Manney, G. L., Pumphrey, H. C., Santee, M. L., Wu, D. L., Cuddy, D. T., Lay, R. R., Loo, M. S., Perun., V. S., Schwartz, M. J., Stek, P. C., Thurstans, R. P., Chandra, K. M., Chavez, M. C., Chen, G., Boyles, M. A., Chudasama, B. V., Dodge, R., Fuller, R. A., Girard, M. A., Jiang, J. H., Jiang, Y., Knosp, B. W., LaBelle, R. C., Lam, J. C., Lee, K. A., Miller, D., Oswald, J. E., Patel, N. C., Pukala, D. M., Quintero, O., Scaff, D. M., Snyder, W. V., Tope, M. C.,Wagner, P. A., and Walch, M. J.: The Earth Observing System Microwave Limb Sounder (EOS MLS) on the Aura satellite, IEEE Trans. Geosci. Remote Sens., 44, 1075-1092, 2006.

Wild, O., Zhu, X., and Prather, M.: Fast-J: Accurate simulation of in- and below- cloud photolysis in tropospheric chemical models, J. Atmos. Chem., 37, 245-282, 2000.

Wu, D. L., Jiang, J. H., Read, W. G., Austin, R. T., David, C. P., Lambert, A., Stephens, G. L., Vane, D. G., and Waters, J. W.: Validation of Aura MLS cloud Ice Water Content (IWC) measurements, J. Geophys. Res., 113, D15S10, doi:10.1029/2007LD008931, 2008.

Wu, S., Mickley, L. J., Jacob, D. J., Logan, J. A., Yantosca, R. M., and Rind, D.: Why are there large differences between models in global budgets of tropospheric ozone?, J. Geophys. Res., 112, D05302, doi:10.1029/2006JD007801, 2007.

Xiao, Y., Logan, J. A., Jacob, D. J., Hudman, R. C., Yantosca, R., and Blake, D. R.: Global budget of ethane and regional constraints on US sources, J. Geophys. Res., 113, D21306, doi:10.1029/2007JD009415, 2008.

Yevich, R. and Logan, J. A.: An assessment of biofuel use and burning of agricultural waste in the developing world, Global Biogeochem. Cy., 17, 1095, doi:10.1029/2002GB001952, 2003.

Zeng, G., Williams, J. E., Fisher, J. A., Emmons, L. K., Jones, N. B., Morgenstern, O., Robinson, J., Smale, D., Paton-Walsh, C., and Griffith, D. W. T.: Multi-model simulation of CO and HCHO in the Southern Hemisphere: comparison with observations and impact of biogenic emissions, Atmos. Chem. Phys., 15, 7217 7245, doi:10.5194/acp-15-7217-2015, 2015.

Zhang, Q., Streets, D. G., Carmichael, G. R., He, K. B., Huo, H., Kannari, A., Klimont, Z., Park, I. S., Reddy, S., Fu, J. S., Chen, D., Duan, L., Lei, Y., Wang, L. T., and Yao, Z. L.: Asian emissions in 2006 for the NASA INTEX-B mission, Atmos. Chem. Phys., 9, 5131-5153, doi:10.5194/acp-9-5131-2009, 2009. 